\title{
DURABILITY OF HEMP CONCRETES EXPOSED TO ACCELERATED ENVIRONMENTAL AGING
}

\author{
Guillaume Delannoy $^{\mathrm{a}}$, Sandrine Marceau ${ }^{\mathrm{a}}$, Philippe Glé ${ }^{\mathrm{bc}}$, Etienne Gourlay ${ }^{\mathrm{b}}$, Marielle Guéguen- \\ Minerbe $^{a}$, Sofiane Amziane ${ }^{d}$, Fabienne Farcas ${ }^{a}$ \\ ${ }^{a}$ MAST-CPDM, Univ Gustave Eiffel, IFSTTAR, F-77454 Marne-la-Vallée, France; \\ gui.delannoy@gmail.com; sandrine.marceau@univ-eiffel.fr; marielle.gueguen@univ-eiffel.fr; \\ fabienne.farcas@univ-eiffel.fr
}

${ }^{\mathrm{b}}$ CEREMA, Laboratory of Strasbourg, 11 rue Jean Mentelin, BP 9, 67035 Strasbourg Cedex 2, France;

philippe.gle@cerema.fr; etienne.gourlay@cerema.fr

${ }^{\circ}$ UMRAE, CEREMA, Univ Gustave Eiffel, IFSTTAR, F-67035 Strasbourg, France;

${ }^{d}$ University of Clermont Auvergne, Institut Pascal, UMR 6602, 63174 Aubière Cedex, France.

\section{sofiane.amziane@uca.fr}

Corresponding author: sandrine.marceau@univ-eiffel.fr

\begin{abstract}
This study examines the evolution of the functional properties of two hemp concretes formulated with two different binders over 2 years in different environmental conditions. Stable environmental conditions $\left(50 \% \mathrm{RH}-20^{\circ} \mathrm{C}\right)$ have been applied to hemp concretes to obtain the reference aging $A_{R E F}$. An accelerated aging process $A_{W D}$ is chosen, consisting of cycles of wetting and drying. In relation to the reference aging, no significant variation of the chemical, microstructural and functional properties is observed, whether in terms of the thermal, acoustic, hydric or mechanical behavior. During accelerated aging, variations of properties are observed: an increase of thermal conductivity, and water vapor sorption capacity for both binders and a decrease of acoustic performance for the limebased binder. No variation of mechanical properties is observed. These results are linked to alterations of the chemical and microstructural properties: hydration and carbonation of the binder, mineralization, swelling and shrinkage and consumption of vegetal walls by micro-organisms. By comparing these results with measurements carried out under real conditions, this work shows that the performance of hemp concretes should remain stable for several years.
\end{abstract}

\section{INTRODUCTION}

Hemp concrete is an insulating material used for its thermal, hygrothermal and acoustic properties [13]. It is composed of vegetal aggregates, called shiv, which are coated and bound by a thin layer of mineral binder ( $<0.5 \mathrm{~mm}$ thickness). The functional properties of the material are related to its microstructure, and in particular to the porosity of hemp shiv [4]. Porosity is a key parameter controlling thermal and acoustic dissipation phenomena in these materials. 
A range of disorders have been observed in early hemp concrete constructions, such as binder applied on its surface, or delamination of renders [5]. These issues stem from an unsuitable implementation of materials, which causes high water content in the hemp concrete, due, for example, to insufficient drying, capillary rise or water infiltration. The validation of construction rules made it possible to greatly reduce the occurrence of these construction defects [6]. Today, with a view to increasing the use of these materials, the question of the evolution of their long-term performance arises. Indeed, the durability of hemp concretes is not yet known, and it is not possible to guarantee that a minimum level of thermal, hygrothermal and acoustic performances will be preserved for a given time. In this context, some reservations still remain that limit the use of these biobased insulating materials.

The evolution of the properties of hemp concretes depends on the conditions of their use and the environment to which they are exposed. Parameters such as relative humidity, temperature, liquid water and UV radiation cause changes in chemical and microstructural properties, altering the functional properties. Previous studies have shown that water has many impacts on the properties of hemp concrete. As a matter of fact, as hemp shiv is hydrophilic, the presence of water leads to a swelling of the aggregates which increases the stresses at the interface between the vegetal particles and the binder [7], and can lessen the mechanical properties of hemp concrete. In addition, the presence of water and mineral binder causes a high $\mathrm{pH}$ within the material, causing alkaline degradation [8] and/or mineralization of shiv $[9,10]$. The moisture content also affects the hydration reactions $[11,12]$ and the carbonation kinetics $[13]$ of mineral binders.

Moreover, the presence of plant-based material in the concretes presents an increased risk of fungal development: during the retting process, the vegetal compounds can serve as nutrients for the development of micro-organisms. These micro-organisms damage the plant structure, resulting in a loss of mechanical properties and an increase of water sorption capacity of hemp concretes [14,15]. A study on the aging of bulk shiv also highlighted the variation of its hydric properties as well as the loss of acoustic properties when it is subjected to cycles of relative humidity ( $98 \%$ for 5 days and $40 \%$ for 2 days) or to outdoor conditions [16]. However, a high relative humidity, greater than $90 \%$, is necessary for the proliferation of microorganisms. Thus, no fungal development is observed on hemp concretes stored at $30^{\circ} \mathrm{C}$ and $80 \% \mathrm{RH}$ for 7 months [17] or submitted to humidification-drying cycles [18].

In recent years, initial studies have focused on the durability of hemp concretes. In order to understand the evolutions of the material's properties, laboratory accelerated aging processes have been proposed. These tests consist of varying the environmental conditions, and particularly the amount of water in the material. Aging protocols are based on variations of relative humidity $[19,20]$, immersion in water [21] and freeze-thaw cycles [17,22]. The materials can also be stored in a humid environment (> $95 \% \mathrm{RH})[10,13]$. During wetting/drying cycles, small variations in functional properties are observed, but the aging durations are too short to draw any conclusions on the durability of hemp concretes using hygrometry as an aging factor [23]. Such aging conditions are close to the actual conditions of use of the material and do not produce changes in the cohesion of the material. During more severe 
aging conditions, such as cycles of immersion in water and drying, leaching of plant or mineral matter concretes are typically used, but rather to accidental situations such as water damage, infiltration or capillary upwelling in a building.

On the basis of the different studies on accelerated aging of vegetal concretes in a laboratory, two aging conditions were chosen in this study to assess the durability of hemp concretes. The first is a static and controlled environment $\left(A_{R E F}\right)$ used as a reference. The second is an accelerated aging process $\left(A_{W D}\right)$, consisting of applying cycles of wetting and drying of the samples, by varying relative humidity, at a temperature favorable to the development of micro-organisms. A multiscale and multidisciplinary approach reveals possible evolutions of functional properties (thermal, acoustic, hydric and mechanical) and allows us to correlate them with an evolution of the microstructural and physicochemical properties of the hemp concretes. In order to study the impact of formulation on all the long-term properties, two binders, commonly used on site, having a different chemical composition, are used. Firstly, the characterization of the functional, microstructural and chemical properties of hemp concretes is presented as a function of time, type of aging and binder used. Then, the link between the different properties of the material is analyzed in order to identify aging indicators.

\section{MATERIALS AND METHODS}

\subsection{Materials}

\subsubsection{Hemp shiv}

A commercial hemp shiv HS for insulation of buildings and labeled for the manufacturing of hemp concrete is used in this study. The main characteristics of the shiv are presented in Table 1: apparent bulk density, fiber and dust contents, initial rate of absorption (IRA), water absorption coefficient $\mathrm{K}_{1}$ and chemical composition. Their particle size distribution and water absorption capacity are plotted in Figure 1. All these parameters are measured according to the recommendations of the RILEM technical group 236-BBM [24] and the standard NF V18-122.

Table 1. Physical parameters and chemical composition of hemp shiv

\begin{tabular}{lclc}
\hline \multicolumn{2}{c}{ Physical parameters } & \multicolumn{1}{c}{ Chemical composition (\%) } \\
\hline Apparent bulk density $\left(\mathrm{kg} \cdot \mathrm{m}^{-3}\right)$ & $118 \pm 3$ & Cellulose & $53.3 \pm 0.9$ \\
Fiber content (\%) & $3.3 \pm 0.6$ & Hemicellulose & $12.1 \pm 0.9$ \\
Dust content (\%) & $0.5 \pm 0.2$ & Lignin & $15.0 \pm 0.2$ \\
Initial rate of water absorption (\%) & $\mathrm{IRA}=209 \pm 9$ & & \\
Water absorption coefficient & $\mathrm{K}_{1}=50 \pm 4$ & Extractive compounds & $20 \pm 2$ \\
$(\% / \log (\mathrm{t} / \mathrm{min}))$ & & & \\
\hline
\end{tabular}



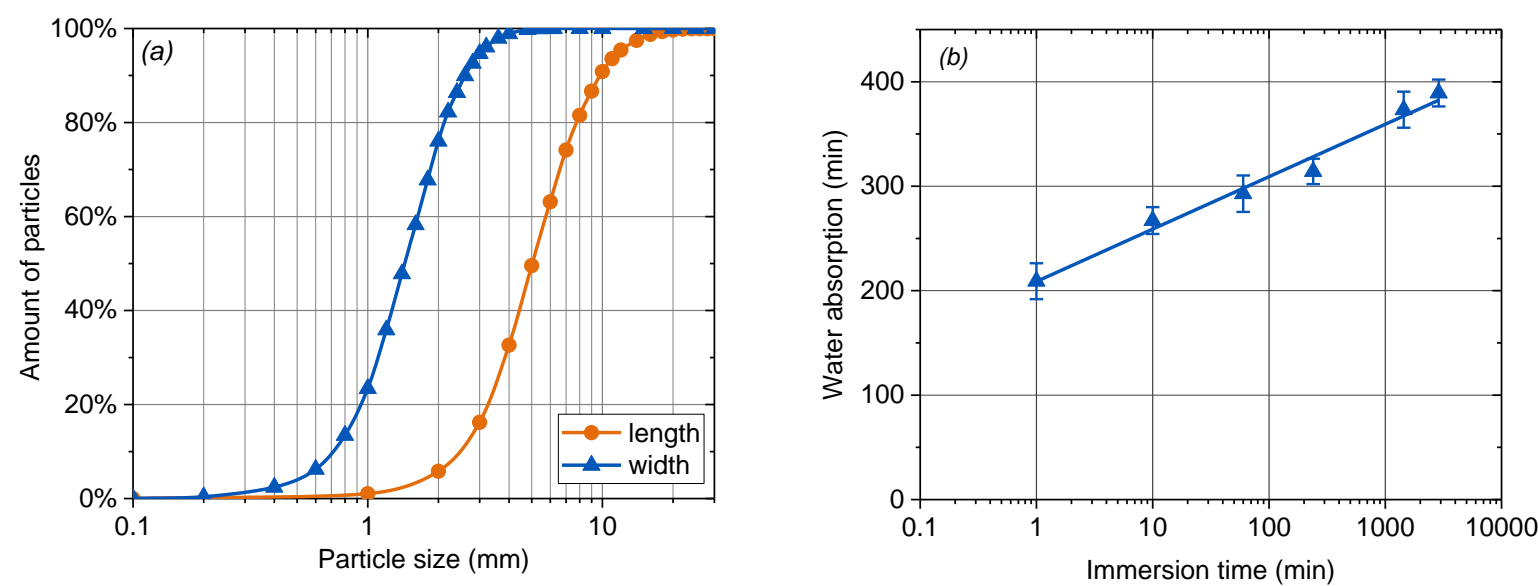

Figure 1. (a) Particle size distribution and (b) water absorption capacity of hemp shiv

\subsubsection{Mineral binders}

Most of hemp concretes are formulated with lime as a binder. Therefore, a commercial binder, composed of $70 \%$ natural hydraulic lime (NHL5), and $30 \%$ hydraulic binders, pozzolans and adjuvants are used for the study. Thermogravimetric analysis shows that $36 \%$ of this binder is composed of aerial lime (Table 2). The other binder used is a hydraulic, prompt natural cement. Flash hydration of aluminates is delayed by the addition of citric acid to delay the setting time.

In this study, the binders will be referred as FL for the lime-based one, and NC for natural cement.

Table 2. Properties of binders: mineralogical composition determined by ICP-AES and thermogravimetric analysis, and apparent density*

\begin{tabular}{ccc}
\hline \multicolumn{3}{c}{ ICP-AES analysis } \\
\hline & $\mathrm{NC}$ & $\mathrm{FL}$ \\
\hline $\mathrm{CaO}$ & $55.1 \%$ & $65.7 \%$ \\
$\mathrm{SiO}_{2}$ & $12.7 \%$ & $10.7 \%$ \\
$\mathrm{Al}_{2} \mathrm{O}_{3}$ & $6.1 \%$ & $2.9 \%$ \\
$\mathrm{Fe}_{2} \mathrm{O}_{3}$ & $1.9 \%$ & $1.4 \%$ \\
$\mathrm{SO}_{3}$ & $3.3 \%$ & $1.9 \%$ \\
$\mathrm{MgO}_{\mathrm{g}}$ & $3.3 \%$ & $1.1 \%$ \\
$\mathrm{~K}_{2} \mathrm{O}$ & $1.1 \%$ & $0.7 \%$ \\
$\mathrm{Na}_{2} \mathrm{O}$ & $0.18 \%$ & $0.1 \%$ \\
\hline
\end{tabular}

\begin{tabular}{lcc}
\hline \multicolumn{3}{c}{ Thermogravimetric analysis } \\
\hline & $\mathrm{NC}$ & $\mathrm{FL}$ \\
\hline Ignition loss $\left(1200^{\circ} \mathrm{C}\right)$ & $11.8 \%$ & $11.4 \%$ \\
Portlandite (aerial lime) & $6.7 \%$ & $36.5 \%$ \\
Calcium carbonate & $24.7 \%$ & $3.0 \%$ \\
& & \\
\hline Apparent density ${ }^{*}\left(\mathrm{~kg} \cdot \mathrm{m}^{-3}\right)$ & $\mathrm{NC}$ & $\mathrm{FL}$ \\
\hline & 700 & $900-1100$ \\
*Supplier's data & & \\
\end{tabular}

The hardening of the lime-based binder consists of three reactions. The first is the hydration of the calcium silicate phases $\left((\mathrm{CaO})_{3}-\mathrm{SiO}_{2}\right.$ and $(\mathrm{CaO})_{2}-\mathrm{SiO}_{2}$ respectively denoted $\mathrm{C}_{3} \mathrm{~S}$ and $\left.\mathrm{C}_{2} \mathrm{~S}\right)$ to form hydrated calcium silicates $(\mathrm{CaO})_{1,7}-\mathrm{SiO}_{2}-\mathrm{H}_{2} \mathrm{O}$, denoted $\left.\mathrm{CSH}\right)$ and calcium dihydroxide $\left(\mathrm{Ca}(\mathrm{OH})_{2}\right)$, also called portlandite or aerial lime (equations 1 and 2). The second reaction takes place between pozzolans, water and portlandite (equation 3) [25]. The final reaction is the carbonation of portlandite (equation 4) and $\mathrm{CSH}$ (equation 5) to form calcium carbonates.

$$
\mathrm{C}_{3} \mathrm{~S}+\mathrm{H}_{2} \mathrm{O} \rightarrow \mathrm{CSH}+\mathrm{Ca}(\mathrm{OH})_{2}
$$




$$
\mathrm{C}_{2} \mathrm{~S}+\mathrm{H}_{2} \mathrm{O} \rightarrow \mathrm{CSH}+\mathrm{Ca}(\mathrm{OH})_{2}
$$

$$
\text { Pozzolans }+\mathrm{Ca}(\mathrm{OH})_{2}+\mathrm{H}_{2} \mathrm{O} \rightarrow \mathrm{CSH}
$$

$$
\mathrm{Ca}(\mathrm{OH})_{2}+\mathrm{CO}_{2} \rightarrow \mathrm{CaCO}_{3}+\mathrm{H}_{2} \mathrm{O}
$$

$$
\mathrm{CSH}+\mathrm{CO}_{2} \rightarrow \mathrm{CaCO}_{3}+\mathrm{H}_{2} \mathrm{O}+\mathrm{SiO}_{2}
$$

In the case of natural cement, the rapid setting is due to hydration reactions of the aluminate phases, present in large quantities (Table 2). For example, $\mathrm{C}_{3} \mathrm{~A}\left(\mathrm{Ca}_{3} \mathrm{Al}_{2} \mathrm{O}_{6}\right)$ phases form hydrated calcium aluminates $\left(\mathrm{C}_{4} \mathrm{AH}_{13}\right.$ or $\left.\mathrm{C}_{2} \mathrm{AH}_{8}\right)$ and sulfoaluminates (AFt or ettringite) in the presence of sulfates (equations 6 and 7) [26]. The long-term hardening of this binder is due to the hydration of $\mathrm{C}_{2} \mathrm{~S}$ (equation 2), which is the major component of natural cement [26] and contributes to mechanical strength from 28 days [27].

$$
\begin{aligned}
& \mathrm{C}_{3} \mathrm{~A}+\mathrm{H}_{2} \mathrm{O} \rightarrow \mathrm{C}_{4} \mathrm{AH}_{13}+\mathrm{C}_{2} \mathrm{AH}_{8} \\
& \mathrm{C}_{3} \mathrm{~A}+\mathrm{H}_{2} \mathrm{O}+\mathrm{SO}_{4}{ }^{2-} \rightarrow \mathrm{AFt}
\end{aligned}
$$

\subsection{Hemp concrete manufacturing and curing conditions}

Two batches of hemp concrete corresponding to a wall formulation are manufactured according to French construction rules [6]. The same formulation is used for both batches, with a total water-tobinder ratio of 1 , and a binder-to-shiv mass ratio of 2 . The shiv is introduced with half the water and the setting retarder for the natural cement, in a mixer suited to hemp concrete (Hemp Eco System mixer $-200 \mathrm{~L}$ ). Then the binder and the remaining water are added. Fresh hemp concrete is then filled into molds and manually compacted to obtain a fresh density of $530 \mathrm{~kg} \cdot \mathrm{m}^{-3}$. The hemp concrete containing the lime-based binder is called FL-HC, and the one containing natural cement is NC-HC.

After manufacturing, the samples are stored for 90 days to ensure the hardening of the binder through hydration and carbonation, as well as the drying of hemp concretes. The specimens are demolded 7 days after their manufacture and kept in a conditioned room (65\% $\mathrm{RH}$ and $\left.20^{\circ} \mathrm{C}\right)$ for 81 days. To control the water content of hemp concretes, which has a significant influence on their properties [28], the samples are dried for two days at $40^{\circ} \mathrm{C}$. At the end of this curing period, the densities of the hemp concretes in the dry state are, respectively, $350 \mathrm{~kg} \cdot \mathrm{m}^{-3}$ and $348 \mathrm{~kg} \cdot \mathrm{m}^{-3}$ for NC-HC and FL-HC. The initial properties of these hemp concretes are detailed in Delannoy et al. [4].

\subsection{Aging protocols}

After the curing period and the drying of hemp concrete samples, they are subjected to two different aging protocols for a period of two years.

The first batch of specimens is stored in a static environment in a conditioned room at $50 \% \mathrm{RH}$ and $20^{\circ} \mathrm{C}$. This aging $A_{R E F}$ is used as a reference.

The second batch of specimens is subjected to accelerated aging in the laboratory. The specimens are exposed to wetting and drying cycles in a climatic chamber at a constant temperature of $30^{\circ} \mathrm{C}$. One cycle lasts one week, with 5 days at $98 \% \mathrm{RH}$ and 2 days at $40 \% \mathrm{RH}$. The choice of these levels 
was made on the basis of a previous study [29] and some additional measures. This aging is denoted $A_{W D}$.

During the two years of aging, samples are taken and analyzed in the initial state after hardening $\left(A_{90}\right)$, then after 3 months, 6 months, 12 months, 18 months and 24 months of aging under $A_{R E F}$ and $A_{W D}$ conditions. All samples are dried for 48 hours at $40^{\circ} \mathrm{C}$ before any characterization.

\subsection{Functional properties}

\subsubsection{Thermal conductivity}

Thermal conductivity $\lambda$ is a parameter that describes the ability of a material to conduct heat. The measurements are carried out by a transient method with the Hot Disk device (measuring time $80 \mathrm{~s}$, heating power $0.1 \mathrm{~W}$ ), on 5 test specimens at $24^{\circ} \mathrm{C}$. The probe is placed between two cylindrical specimens $10 \mathrm{~cm}$ in diameter and $4 \mathrm{~cm}$ thick. The device is covered with a bell jar to limit convection. These non-destructive tests are carried out on the same batch of samples.

\subsubsection{Acoustical properties}

The acoustic properties are measured using a Kundt tube (AcoustiTube AFD). Two types of properties are recorded: the sound absorption coefficient $\alpha$ and the transmission loss TL. The sound absorption coefficient is the fraction of sound energy absorbed by a material. Its value is expressed between 1 (total absorption, no reflection) and 0 (no absorption, total reflection). The transmission loss, expressed in decibels, corresponds to the sound insulation provided by the material.

The tests are conducted over a frequency range [250-2000 Hz] on the same samples as those used for thermal measurements. In order to avoid any peripheral leakage and sound loss during the measurement, the gap between the specimen and the tube is filled with Teflon tape and petroleum jelly. These non-destructive tests are carried out on the same batch of samples.

\subsubsection{Compressive strength}

The compressive strength of hemp concrete is measured as recommended by Rilem Technical Committee TC-236 BBM [30]. Three cylindrical specimens $10 \mathrm{~cm}$ in diameter and $20 \mathrm{~cm}$ in height are used for the measurements and a Zwick hydraulic press is used. Three new specimen are analyzed for each aging time.

\subsubsection{Sorption isotherms}

The hydric behavior is determined on the basis of the water vapor sorption isotherms using a DVS system (Dynamic Vapor Sorption - SMS DVS Advantage). A sample of a few tens of $\mathrm{mg}$ is extracted from the samples collected after compression tests. It is suspended in a microbalance within a sealed thermostatically controlled chamber at $25^{\circ} \mathrm{C}$. The moisture content is determined at successive stages of increasing relative humidity. Change of stage occurs if the variation in mass is less than $0.005 \%$ per minute for $30 \mathrm{~min}$. Failing that, the maximum duration of a stage is $12 \mathrm{~h}$. Sorption isotherms are obtained by plotting mass change against relative humidity $(\mathrm{RH})$ and illustrate the water vapor sorption capacity as a function of the relative humidity. 
The water content $\omega$ is calculated by means of the following equation:

$$
\omega=\frac{m_{D V S}-m_{0}}{m_{0}}
$$

where $m_{D V S}$ is the mass recorded at the end of each stage and $m_{0}$ the mass of the dry sample.

To describe the overall behavior of isotherms, the GAB model (Equation 9) is used with the experimental data, as described in other studies [31]. The GAB model is physically valid when there is no capillary condensation $(<40 \% \mathrm{RH})$. However, it fits with experimental data over the whole $\mathrm{RH}$ range.

$$
\omega=\omega_{\mathrm{m}} \frac{\mathrm{RH} \cdot \mathrm{C} \cdot \mathrm{K}}{(1-\mathrm{RH} \cdot \mathrm{K})(1+\mathrm{RH} \cdot \mathrm{C} \cdot \mathrm{K}-\mathrm{RH} \cdot \mathrm{K})}
$$

with $\omega_{\mathrm{m}}$ representing the monomolecular water content $\left(\mathrm{kg} \cdot \mathrm{kg}^{-1}\right), \mathrm{RH}$ the relative humidity, and $\mathrm{C}$ and $\mathrm{K}$ the fitting parameters:

From this model, the specific surface area $S_{m}\left(m^{2} \cdot g^{-1}\right)$ of the material is given by the following equation:

$$
S_{m}=\sigma_{m} \cdot N \cdot \frac{\omega_{m}}{M}
$$

with $\sigma_{\mathrm{m}}$ being the surface of an adsorbed water molecule $\left(\approx 10 \AA^{2}\right), N$ the Avogadro constant $(6.023 \times$ $\left.10^{23} \mathrm{~mol}^{-1}\right)$ and $\mathrm{M}$ the molar mass of water $\left(18 \mathrm{~g} \cdot \mathrm{mol}^{-1}\right)$.

\subsection{Microstructure}

The microstructure of hemp concretes is characterized by scanning electron microscopy observations, density measurements and acoustic parameters. Scanning electron microscopy (SEM) (FEI Quanta 400 ) allows a qualitative analysis of the microstructure of hemp concretes extracted from the samples collected after compression tests. Two detection modes are used: secondary electrons (SE) for cuts of aggregates from hemp concrete and backscattered electrons (BSE) for fractions of hemp concretes embedded in a resin, sawn, polished and metallized.

In quantitative terms, the microstructure of hemp concretes can be described by the volume fractions of the different phases of the material, illustrated in Figure 2. Hemp concrete consists of a skeleton comprising the plant cell walls of the hemp $\left(\eta_{\text {cell wall }}\right)$ and the binder $\left(\eta_{\text {binder }}\right)$ that surrounds them, as well as different types of porosities $\Phi$. The non-optimal arrangement of particles creates voids or pores between particles whose sizes are of the order of a millimeter. They constitute the interparticular porosity $\Phi_{\text {inter }}$ of the material. Shiv also has an internal porosity $\Phi_{\text {intra }}$, consisting of a succession of plant cells, tracheids and vessels. Tracheids are the most common cells, and have a diameter of 10 to $20 \mu \mathrm{m}$. The vessels are less numerous and have a larger diameter, around $50 \mu \mathrm{m}$. The cells are connected by pits, whose diameter is 1 to $2 \mu \mathrm{m}$ [32]. Porosities are also present inside the binder layer. Their diameter is the order of a micrometer, up to a nanometer between hydrates. 
Volume fractions of hemp concretes

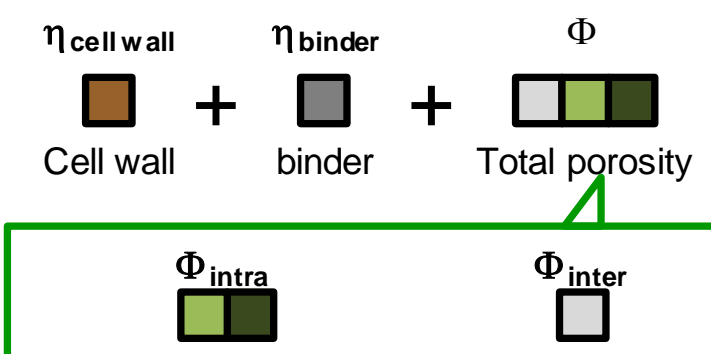

Intraparticular porosity

Interparticular

(Binder porosity and porosity shiv porosity)

\section{Diameter Diameter Diameter $\approx 10-20 \mu \mathrm{m} \quad \approx 50-80 \mu \mathrm{m} \quad \approx 1-2 \mu \mathrm{m}$}

Figure 2. Framework of different phase volume fractions in hemp concretes

Given the size of the interparticle pores, the interparticular porosity $\Phi_{\text {inter }}$ is expected to be open and accessible to a liquid or gas [2]. On the other hand, intraparticular porosity $\Phi_{\text {intra }}$ is thinner and can be either open ( $\left.\Phi_{\text {intra_open }}\right)$, open but not accessible to fluids when the inlet diameter of pores is too small, or closed, so inaccessible ( $\left.\Phi_{\text {intra_closed }}\right)$. These different types of porosities have already been observed on bulk hemp shiv [16].

To quantify these different phases after different aging times, the open air porosity $\Phi_{\text {air }}$ of hemp concretes is measured for the same set of four cylindrical samples of hemp concrete $(3 \mathrm{~cm}$ in diameter and $4 \mathrm{~cm}$ in height) using an air porosimeter as described by Leclaire et al. [33]. $\Phi_{\text {air }}$ represents the volume fraction of open porosity, which is the sum of the interparticle porosity $\Phi_{\text {inter }}$ and the open intraparticle porosity $\Phi_{\text {intra_open. }}$ The skeletal volume of hemp concrete $V_{\text {sk }}$ is determined by BoyleMariotte's law. Knowing the mass $m$ of the sample, we calculate the skeletal density $\rho_{\mathrm{sk}}$ by applying equation 11. During measurement, the volume of closed pores is included in the skeletal volume.

$$
\rho_{\mathrm{sk}}=\frac{\mathrm{m}}{\mathrm{v}_{\mathrm{sk}}}
$$

From the hemp concretes skeletal density $\rho_{\text {sk }}$ and bulk density $\rho$ values, the open porosity is calculated according to equation 12 .

$$
\Phi_{\text {air }}=1-\frac{\rho}{\rho_{\text {sk }}}
$$

Other parameters describing the microstructure of the material are obtained from the acoustic measurements [34]:

- $\Phi_{\text {acou, }}$ effective porosity in acoustics;

$\sigma$, airflow resistance of the material; 
$\alpha_{\infty}$, tortuosity describing the sinuosity of the porous network;

- $\Lambda$, viscous characteristic length corresponding to an estimation of the size of the interconnections between pores.

\subsection{Chemical analysis of binders}

The chemical composition of the binders is determined on a sample of hemp concrete manually crushed with a pestle and mortar to separate the mineral part from the shiv and sieved at $315 \mu \mathrm{m}$. Thermogravimetric and X-ray diffraction have been used on binder powders.

Thermogravimetric analysis (ATG, Netzsch STA 449 F1 Jupiter) is coupled with a mass spectrometer (Netzsch QMS 403 C Quadrupole). The thermal analysis is carried out between $40^{\circ} \mathrm{C}$ and $1200^{\circ} \mathrm{C}$ at $10^{\circ} \mathrm{C} \cdot \mathrm{min}^{-1}$. The loss of mass measured between $100^{\circ} \mathrm{C}$ and $400^{\circ} \mathrm{C}$ is attributed to the dehydration of the hydrated phases, between $400^{\circ} \mathrm{C}$ and $530^{\circ} \mathrm{C}$ to the decomposition of the portlandite and between $530^{\circ} \mathrm{C}$ and $1000^{\circ} \mathrm{C}$ to decarbonation of the calcium carbonates.

X-ray diffraction experiments are performed on a Philips PW 1830 diffractometer with Cobalt Ka wavelength and 0.02 scan step size.

\subsection{Statistical processing of data}

A one-parameter analysis of variance (ANOVA) is performed on the results obtained at different dates of the same formulation kept under the same aging conditions (Excel - XLToolbox - modified version of Levene's test [35]). This test determines whether the evolutions of properties observed over time are statistically significant. At the end of this test, the probability $p$ that there is no difference between the different groups of values is calculated. If $p$ is greater than $5 \%$, then it is estimated that there is no difference between different groups of values, and if $p$ is less than $5 \%$, statistically significant differences are obtained. The probabilities $\mathrm{p}$ are calculated for all aging periods, or between two given aging periods of $x$ and $y$ months (in this case, denoted as $p_{x-y}$ ).

\section{RESULTS}

\subsection{Functional properties}

\subsubsection{Thermal properties}

The thermal conductivity results for both formulations of hemp concretes and for both types of aging at different times are shown in Figure 3. For aging $A_{R E F}$, no significant variation in thermal conductivity is observed for two years $(p>0.68)$. In contrast, with aging $A_{W D}$, the thermal conductivity increase is about $19 \%$ for FL-HC after 24 months and 7\% for NC-HC. These changes are significant after 6 months of aging for FL-HC $\left(\mathrm{p}_{0-6}=10^{-3}\right.$ and $\left.\mathrm{p}_{0-24}=3 \cdot 6 \cdot 10^{-6}\right)$. In the case of $\mathrm{NC}-\mathrm{HC}$, the conductivity increases significantly only after 18 months of $A_{W D}$ aging $\left(p_{0-18}=5.10^{-2}\right.$ and $\left.p_{0-24}=3.5 .10^{-3}\right)$. 

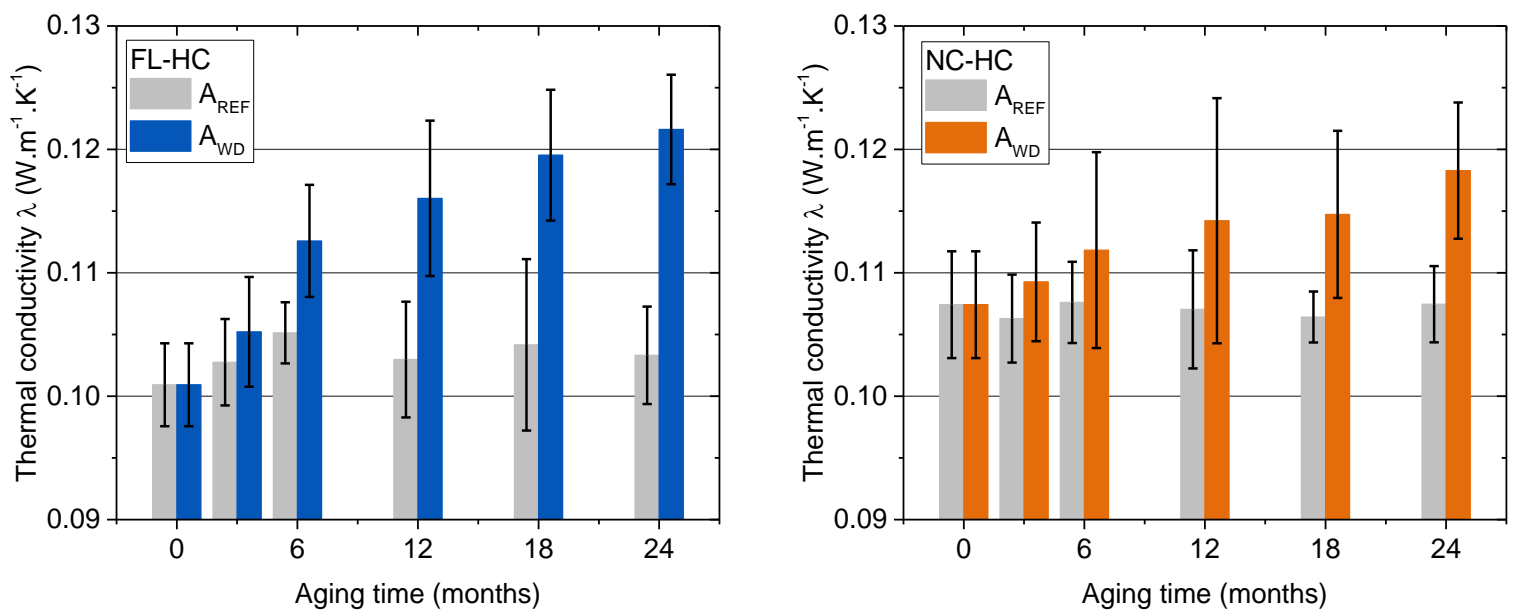

Figure 3. Evolution of the thermal conductivity of FL-HC and $\mathrm{NC}-\mathrm{HC}$ concretes during $A_{R E F}$ and $A_{W D}$ aging

\subsubsection{Acoustic behavior}

The acoustic properties of hemp concretes are presented in Figure 4. These figures illustrate the variation of the sound absorption coefficient $\alpha$ and of transmission loss TL as a function of frequency for both types of concrete and both aging processes.

For both formulations, no significant difference was observed during the two years of aging under reference conditions $A_{R E F}$. The curves measured for $\alpha$ and TL are in a range represented by a gray band in Figure 4.

For $A_{W D}$ aging, no significant variation is visible for NC-HC: the set of curves is included in the $A_{R E F}$ aging batch of curves for both the sound absorption coefficient $\alpha$ and the transmission loss TL. On the other hand, for FL-HC, there is a slight shift of the maximum of $\alpha$ towards the higher frequencies, from 1250 to $1350 \mathrm{~Hz}$, with a slight decrease of the maximum value, from 0.98 to 0.95 . This deviation occurs between 0 and 3 months. For longer aging times, the results remain similar to those obtained at three months. The same shift is observed for the transmission loss with a decrease of TL between 0 and 3 months, then a constant behavior between 3 and 24 months. 

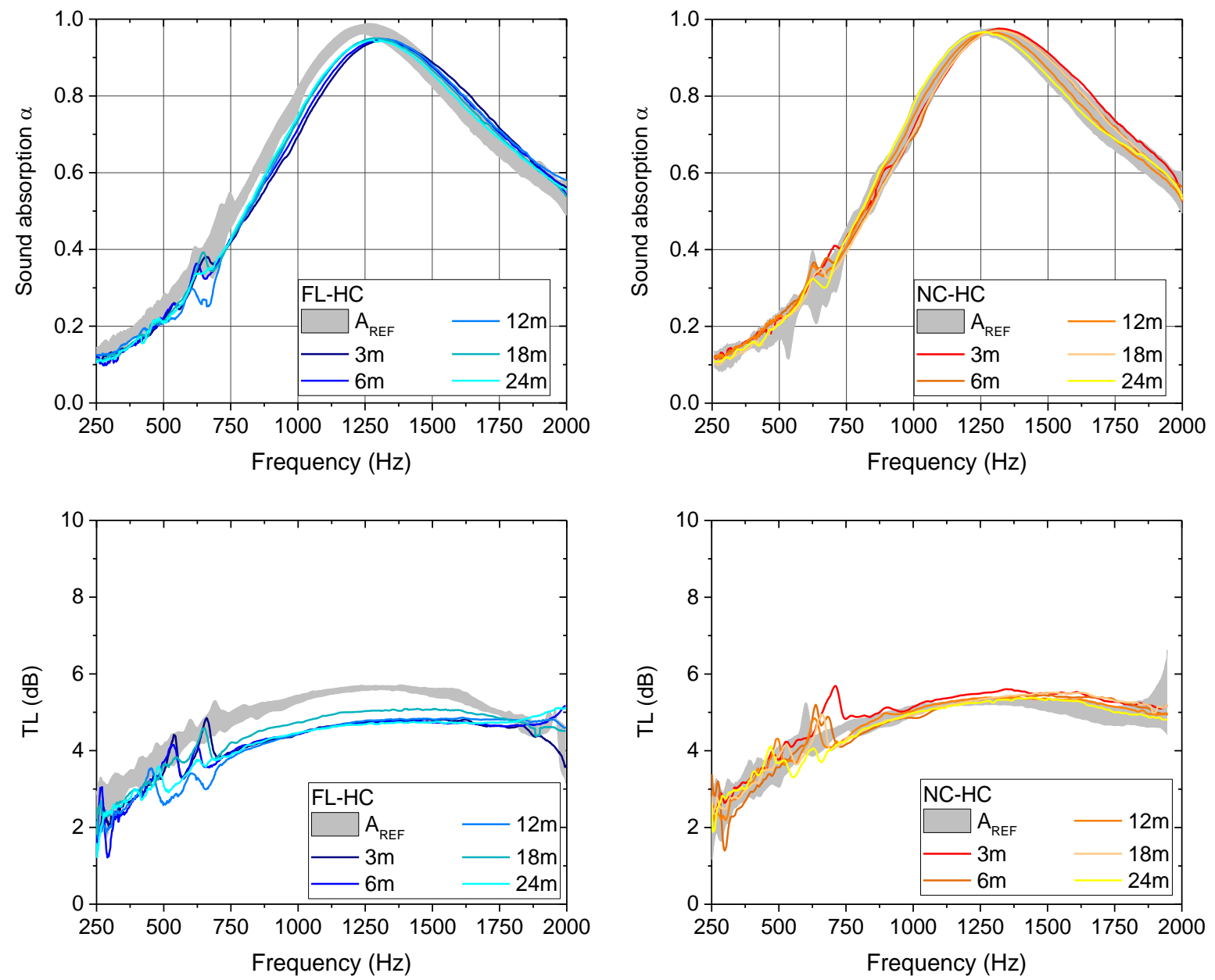

Figure 4. Sound absorption and transmission loss for FL-HC and NC-HC concretes as a function of time and aging types $A_{R E F}$ and $A_{W D}$

\subsubsection{Hydric properties}

The sorption isotherms shown in Figure 5 are plotted for FL-HC and NC-HC at $\mathrm{A}_{90}$ and after 12 and 18 months of accelerated aging $A_{W D}$. From $80 \% \mathrm{RH}$, the mass of the sample does not reach a constant value before the 12 hours of measurement. Therefore, the measured masses do not correspond to the behavior of hemp concretes at high humidity and only the values obtained for relative humidity below $60 \% \mathrm{RH}$ will be analyzed later in this section.

The isotherms obtained are S-shaped and can be classified as type II according to IUPAC classification [36]. These results are consistent with previous studies on hemp concrete [37] since type II isotherms are obtained for macroporous solids. The inflexion point indicates the stage at which monolayer coverage is complete and multilayer adsorption about to begin. For both formulations, there is an increase in the water vapor sorption capacity between 20 and $60 \% \mathrm{RH}$ after 18 months of $A_{W D}$. This increase in water content does not occur at the same time for both formulations. Indeed, a modification of the isotherm profile is visible from 12 months for NC-HC whereas no change is observed for FL-HC at this time. 

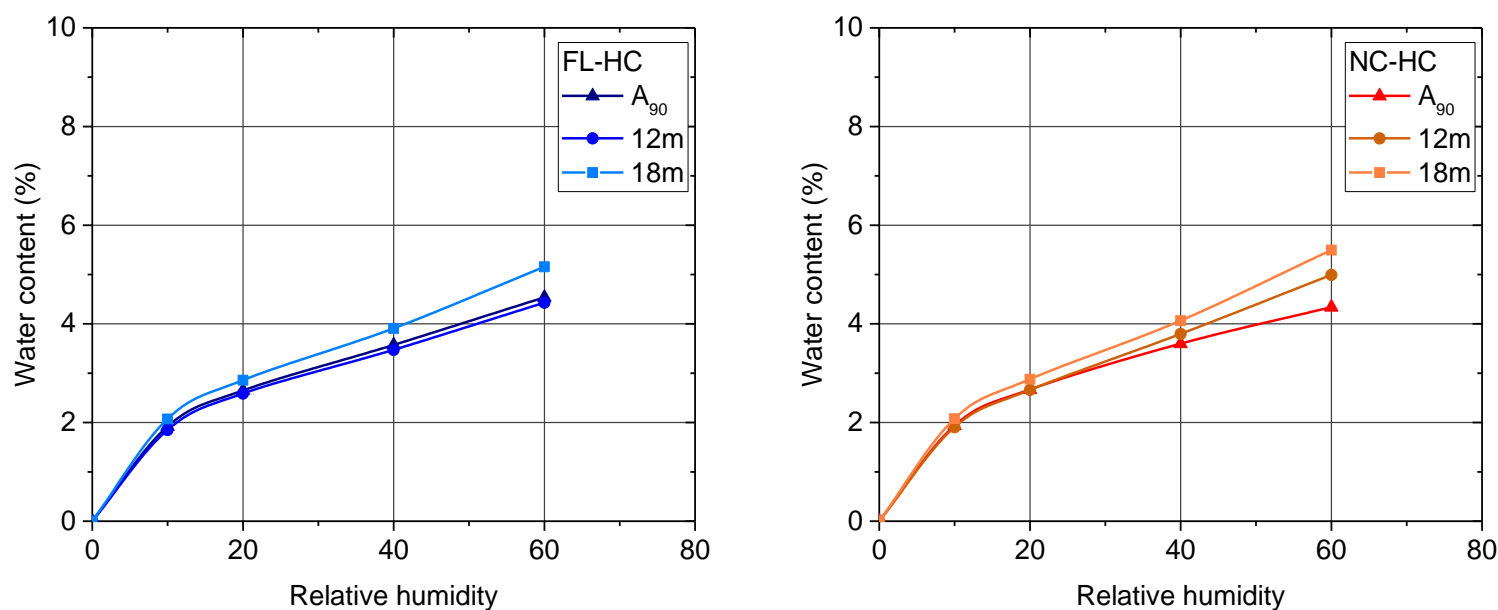

Figure 5. Water vapor sorption isotherms for FL-HC and NC-HC at $A_{90}$ and after 12 and 18 months of $A_{W D}$ aging

The water vapor sorption specific surfaces are estimated from the GAB model (equation 10), whose values as well as the parameters of the model are presented in Table 3. It is observed that the specific sorption surface increases by more than $30 \%$ between $A_{90}$ and 18 months of aging $A_{W D}$. Therefore, $A_{W D}$ aging increases the capacity of hemp concretes to absorb water vapor.

Table 3. Fitting parameters from the GAB model and specific surfaces of FL-HC and NC-HC concretes at $A_{90}$ and after 12 and 18 months of $A_{W D}$ aging

\begin{tabular}{|c|c|c|c|c|c|}
\hline & & \multicolumn{3}{|c|}{ Fitting parameters of GAB model } & \multirow{2}{*}{ Specific surface $\left(\mathrm{m}^{2} \cdot \mathrm{g}^{-1}\right.$} \\
\hline & & $\omega_{m}\left(\mathrm{~kg} \mathrm{~kg}^{-1}\right)$ & $\mathrm{C}$ & K & \\
\hline \multirow{3}{*}{$\mathrm{FL}-\mathrm{HC}$} & $\mathrm{A}_{90}$ & 0.021 & 163 & 0.86 & 71 \\
\hline & $12 m A_{W D}$ & 0.023 & 45 & 0.83 & 78 \\
\hline & $18 m A_{W D}$ & 0.028 & 27 & 0.79 & 95 \\
\hline \multirow{3}{*}{$\mathrm{NC}-\mathrm{HC}$} & $\mathrm{A}_{90}$ & 0.021 & 138 & 0.87 & 72 \\
\hline & $12 m A_{W D}$ & 0.027 & 24 & 0.82 & 90 \\
\hline & $18 m A_{W D}$ & 0.029 & 23 & 0.83 & 97 \\
\hline
\end{tabular}

\subsubsection{Mechanical properties}

The compressive strengths of specimens of hemp concretes are presented in Figure 6. In view of the values obtained and their dispersion, no significant evolution of the mechanical behavior is observed, whatever the formulation and the type of aging ( $p>0.29)$. As discussed during the characterization of hemp concretes before aging [4], the low measured mechanical resistance results from an incomplete hydration of the binders. Their setting is delayed because of the molecules extracted from particles, such as sugars [38]. 


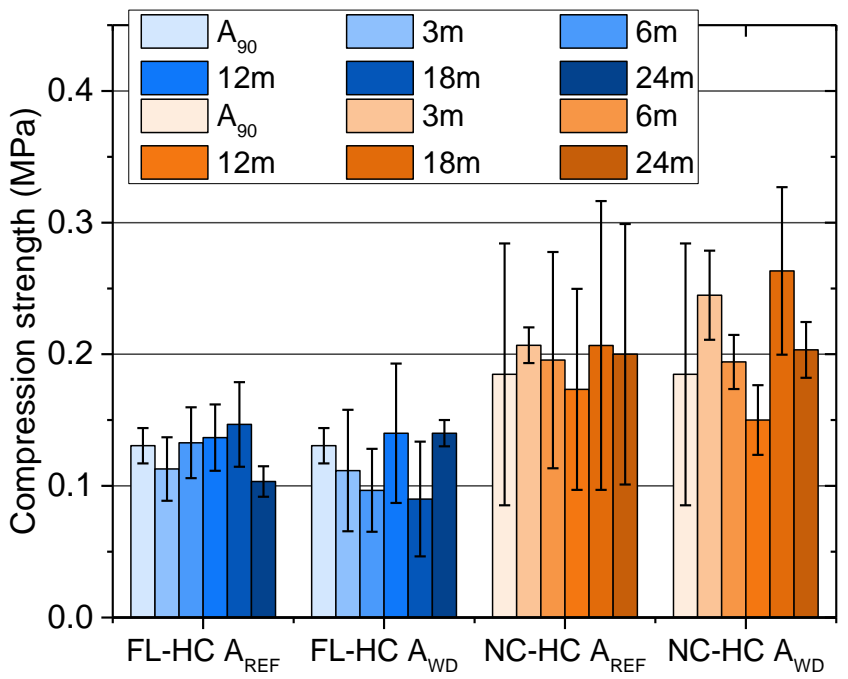

Figure 6. Compression strength for hemp concretes as a function of aging type and time

\subsection{Mineralogical composition of binders}

Mineralogical analyses are carried out at $A_{90}$ and at different aging times on the binder powders collected from the surface and in the core of the hemp concrete specimens. They demonstrate the evolution of the proportions of the different compounds in the binders over time for the two aging conditions. The syntheses of the results obtained by X-ray diffraction and thermogravimetric analysis of the mineral part of the concretes are presented in Figure 7 for NC-HC and FL-HC. The four most abundant phases are represented: non hydrated compounds (anhydrous), hydrates, portlandite and calcium carbonates.

Comparing the quantity of anhydrous compounds measured on the non-hydrated binders and after the three months of hardening $\left(A_{90}\right)$, it is observed that the hydration is not complete for either NC or for $\mathrm{FL}$, as observed previously $[4,38]$. These components still represent more than $30 \%$ of $F L$ binder in the core of the samples, and about $20 \%$ in the case of natural cement NC. During these three months of hardening, the carbonation of portlandite is visible by the presence of calcium carbonates. Hydration and carbonation reactions are more advanced on the surface than in the core of the samples for both binders.

After 24 months of storage in the reference conditions $A_{R E F}$, no significant variation in the chemical composition of the binders collected from hemp concretes is observed, either at the core or at the surface of the samples, whatever the formulation. On the other hand, during $A_{W D}$ aging, hydration and carbonation reactions of the binder continue. These reactions are prominent on the surface, where a total hydration of the natural cement NC can be observed after 24 months. In the core of the samples, the progress of the reactions is slower for $\mathrm{NC}-\mathrm{HC}$ concretes, with a decrease of $2 \%$ of the anhydrous content compared to $9 \%$ for FL-HC. In the case of the lime formulated binder FL, hydration and carbonation take place essentially during the first three months of aging. From 3 to 24 months, the mineral phases no longer evolve at the surface but continue to do so in the core of the specimen. 

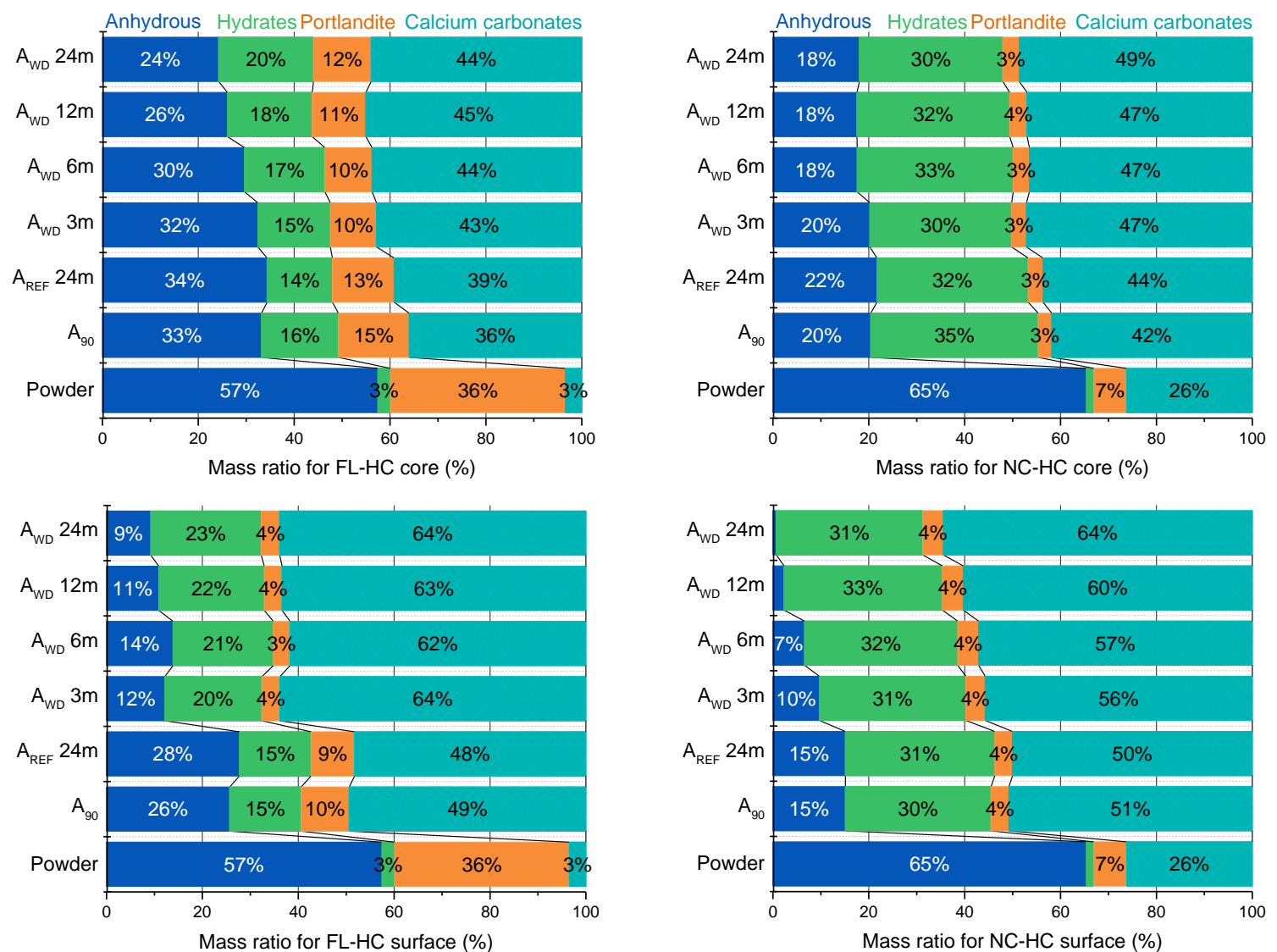

Figure 7. Mineralogical composition of binders FL (left) and NC (right) in the core (top) and at the surface (down) of concrete samples and as a function of hardening and aging time

\subsection{Microstructural properties}

\subsubsection{Evolution of density}

The variation of the bulk density of hemp concretes $\rho$ during the two years of aging is presented in Figure 8 . The assumption is made that the volume of dry specimens no longer varies after curing.

For the reference aging $A_{R E F}$, a decrease in density of about $2 \%$ and $3 \%$ is observed for $\mathrm{NC}-\mathrm{HC}$ and FL-HC, respectively. The density of the samples then stabilizes up to 18 months and a slight decrease is observed at 24 months. The decrease of density measured are due to the loss of weakly bound particles during sample handling.

In contrast, during accelerated aging $A_{W D}$, an increase of density is visible over time and more significantly for FL-HC. This increase occurs up to 18 months $\left(p_{0-18}=3.3 .10^{-5}\right)$, then the density stabilizes at 24 months $\left(p_{18-24}=0.83\right)$. Assuming that the mass loss due to handling of the test pieces observed on $A_{R E F}$ is the same for all the samples, the total density increase of the test specimens subjected to aging $A_{W D}$ can be estimated at 10\% and 5\% respectively for FL-HC and NC-HC after 24 months of aging. 


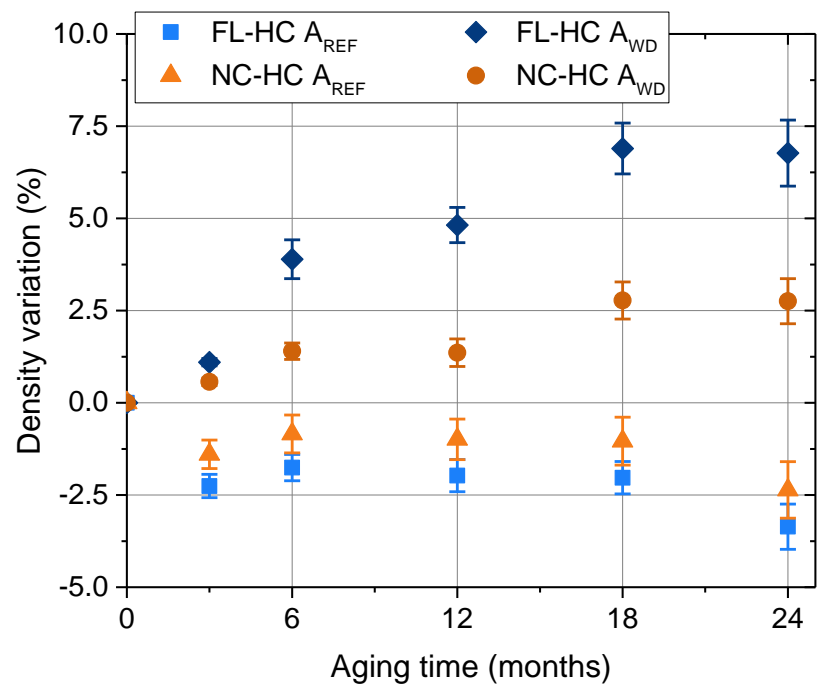

Figure 8. Evolution of density of hemp concretes as a function of time and aging type

The skeleton density of hemp concretes measured by air porosimetry during $A_{R E F}$ and $A_{W D}$ aging is shown in Figure 9. No significant variation over time is visible for either formulation exposed to the reference environment $A_{R E F}(p=0.42)$, and the range of values obtained is represented by a gray band in Figure 9. In contrast, the skeletal density increases during $A_{W D}$ aging between 0 and 18 months. This increase is more obvious for FL-HC $\left(25 \%\right.$ increase $\left.-p=3.5 .10^{-14}\right)$ than for NC-HC $(16 \%$ increase $\left.-p=1.6 .10^{-12}\right)$. Between 18 and 24 months, the skeletal density is constant for FL-HC $\left(p_{18-24}\right.$ $=0.5)$ and decreases for NC-HC $\left(p_{18-24}=1.7 .10^{-2}\right)$.
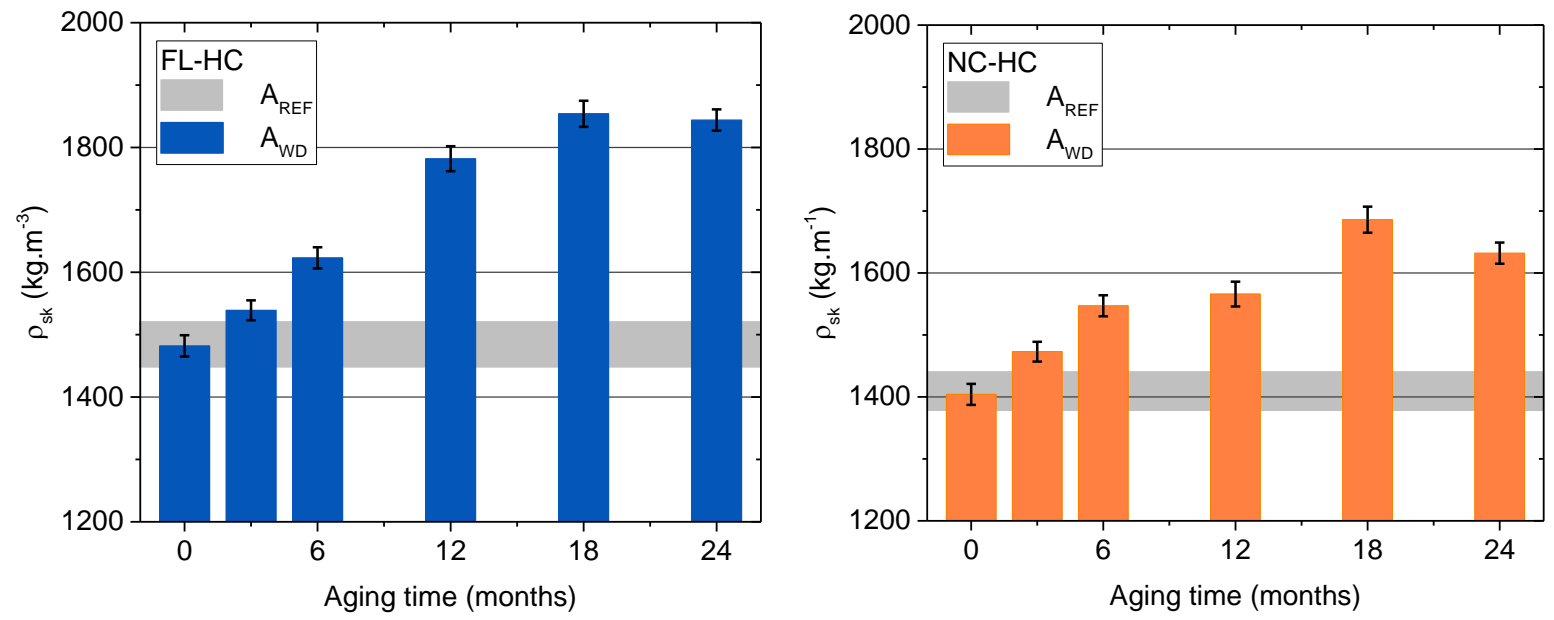

Figure 9. Evolution of the skeleton density of hemp concretes as a function of time and aging type

\subsubsection{Porosity}

From density and skeleton density values, open air porosity $\Phi_{\text {air }}$ of hemp concretes can be calculated and the results are shown in Figure 10. $\Phi_{\text {air }}$ is stable for $A_{R E F}$ aging for both types of binders $(p>0.41)$. On the other hand, for $A_{W D}$ accelerated aging, the open porosity values increase for FL-HC up to 12 months and then stabilize $\left(p_{0-12}=2.3 \cdot 10^{-5}-p_{12-24}=0.6\right)$. For NC-HC, the porosity increases over the first 18 months and decreases between 18 and 24 months $\left(p_{0-18}=2 \cdot 9 \cdot 10^{-5}-p_{18-24}=1 \cdot 3 \cdot 10^{-2}\right)$. For both 
types of hemp concretes, the increase in porosity during the 24 months of accelerated aging is between 0.03 and 0.04 .
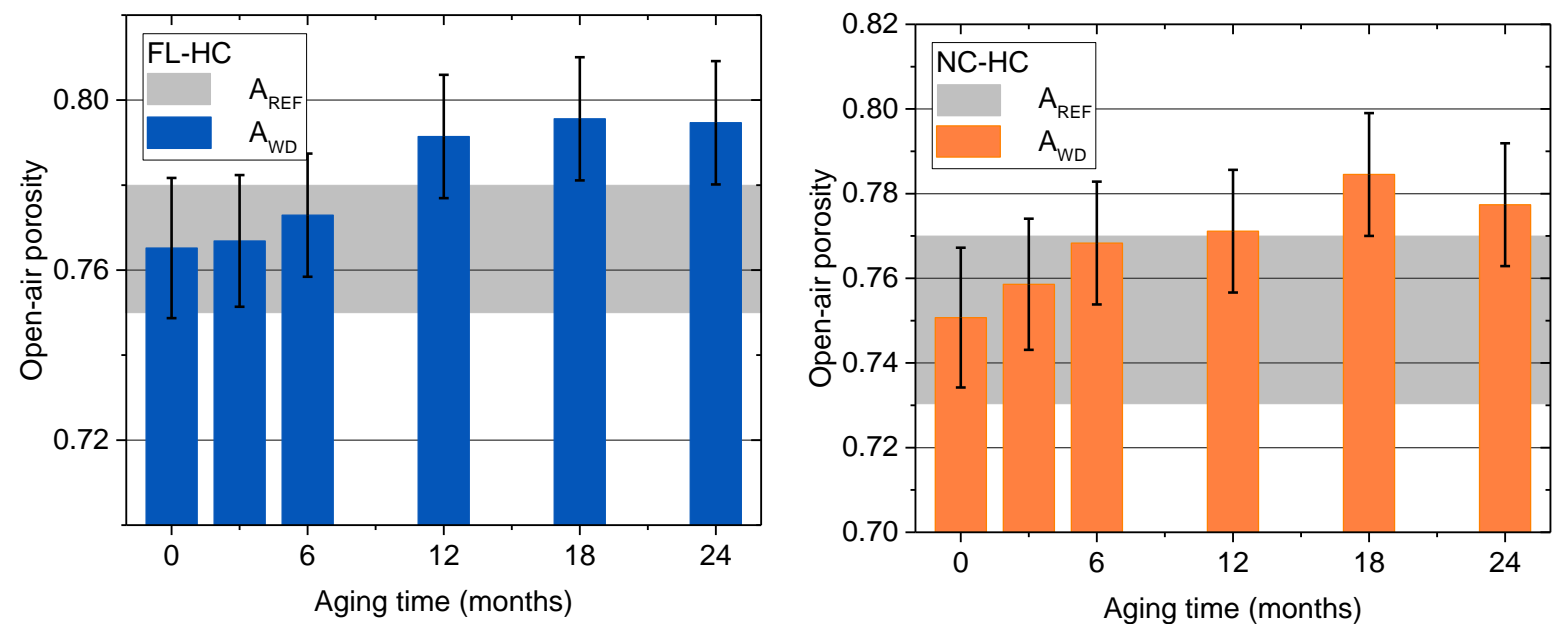

Figure 10. Evolution of the open-air porosity of hemp concretes as a function of time and aging type

\subsubsection{Scanning electron microscopy observations}

Scanning electron microscopy observations were carried out on both concretes to qualitatively observe the evolution of their microstructure during aging.

Representative images of the samples after three months of curing and after 24 months in the $A_{R E F}$ environment are shown in Figure 11. On these images, several hemp particles are observed in mid-range gray, covered with a binder layer in light gray. The interparticle porosity $\Phi_{\text {inter }}$, corresponding to the darkest areas, is also visible. Comparing the observations made at $A_{90}$ and during the reference aging, no variation of microstructure can be highlighted. 

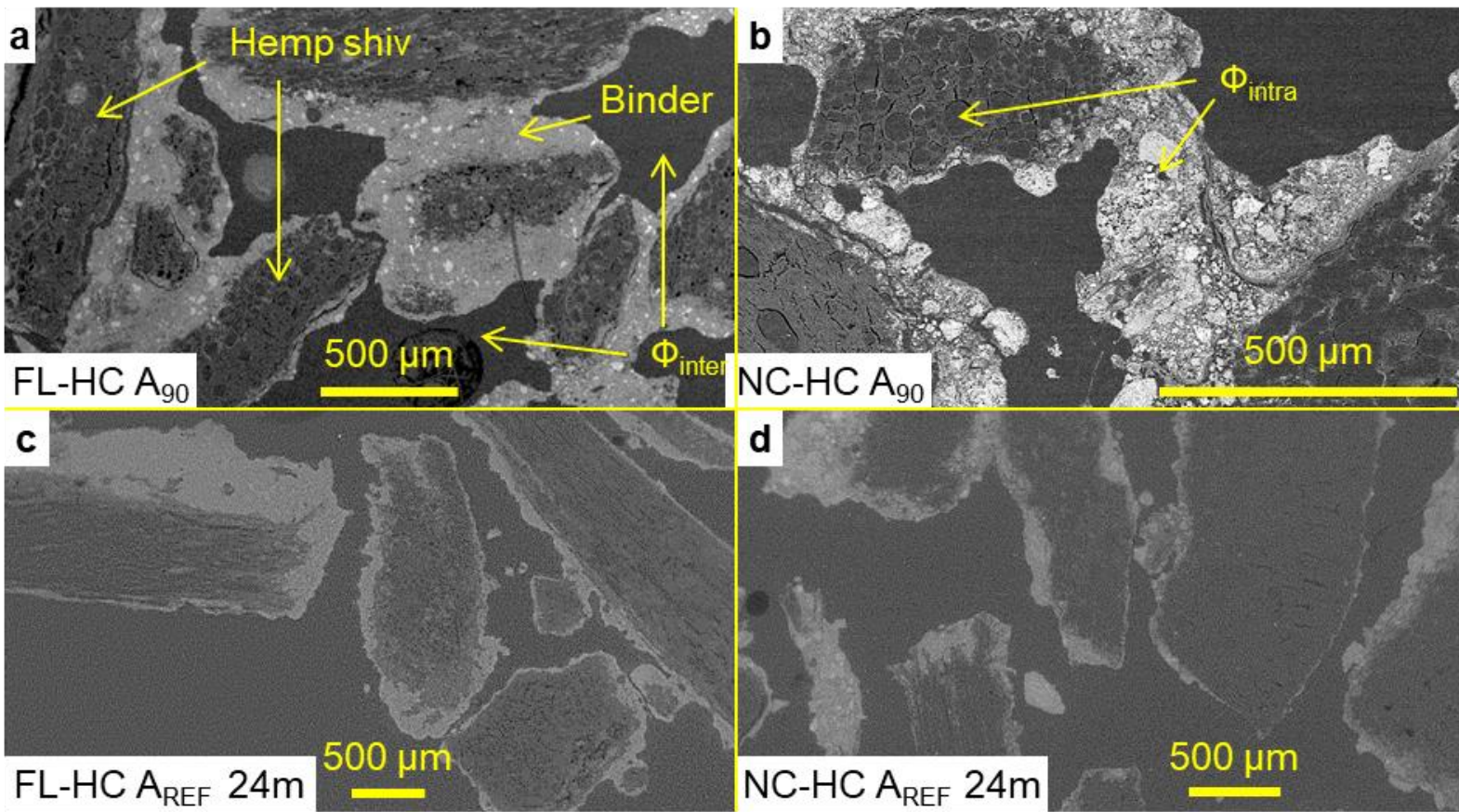

d

Figure 11. SEM observations of hemp concretes after 3 months of curing $\left(A_{90}\right)$ and 24 months of storage in reference conditions $A_{R E F}$

SEM observations carried out during $A_{W D}$ accelerated aging are shown in Figure 12. EDX mappings of these surfaces are also presented for images 12-c and 12- $d$. These observations show a higher amount of binder in the porosity of vegetal particles for FL-HC type concretes (Figure 12-d). EDX mapping confirms this observation and allows us to identify the presence of calcium within the aggregates of FL-HC concretes, visible in yellow in Figure 12-d. This is an indication of the presence of portlandite or calcium carbonates in their porosity. During the stages of wetting at $98 \% \mathrm{RH}$, the calcic phases are dissolved, diffuse into the porosities of the aggregates and re-precipitate into these porosities during the drying phases. This layer of binder deposited on the cell walls indicates mineralization of the plant aggregates, as already observed in hemp $[9,10]$. 

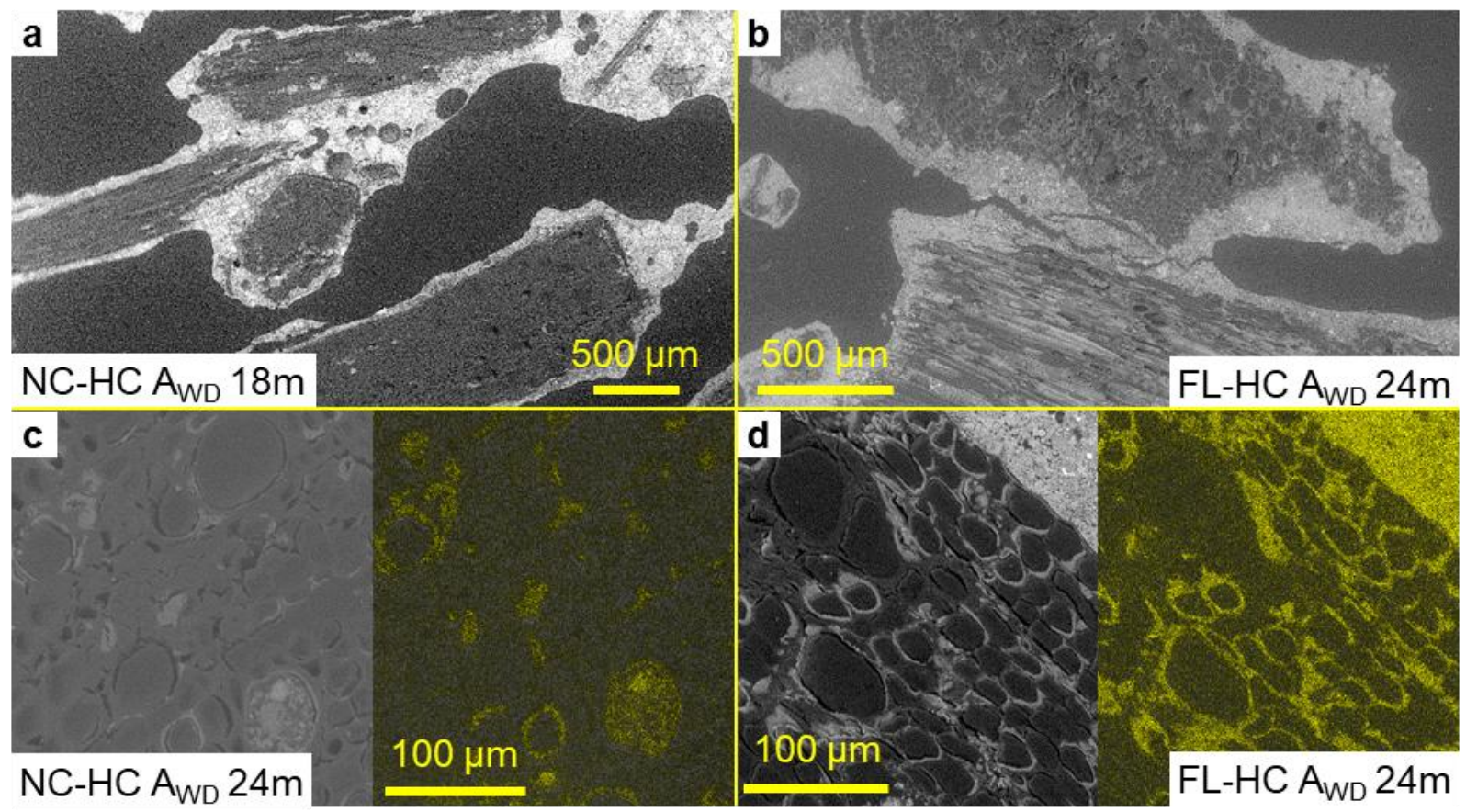

Figure 12. SEM observations of hemp concretes during $A_{W D}$ aging (a) slightly mineralized hemp shiv in $\mathrm{NH}-\mathrm{HC}$ after 18 months, (b) mineralization after 24 months in FL-HC, (c) NC-HC after 24 months with EDX Ca mapping, (d) FL-HC after 24 months with EDX Ca mapping

These observations also reveal cracks within the hemp shiv. The amount of such cracks increases with $A_{W D}$ aging time for both hemp concretes (Figure 13). Generally, they are a few hundred micrometers in size (Figure 13-a), but they can also be larger as shown in Figure 13-b.
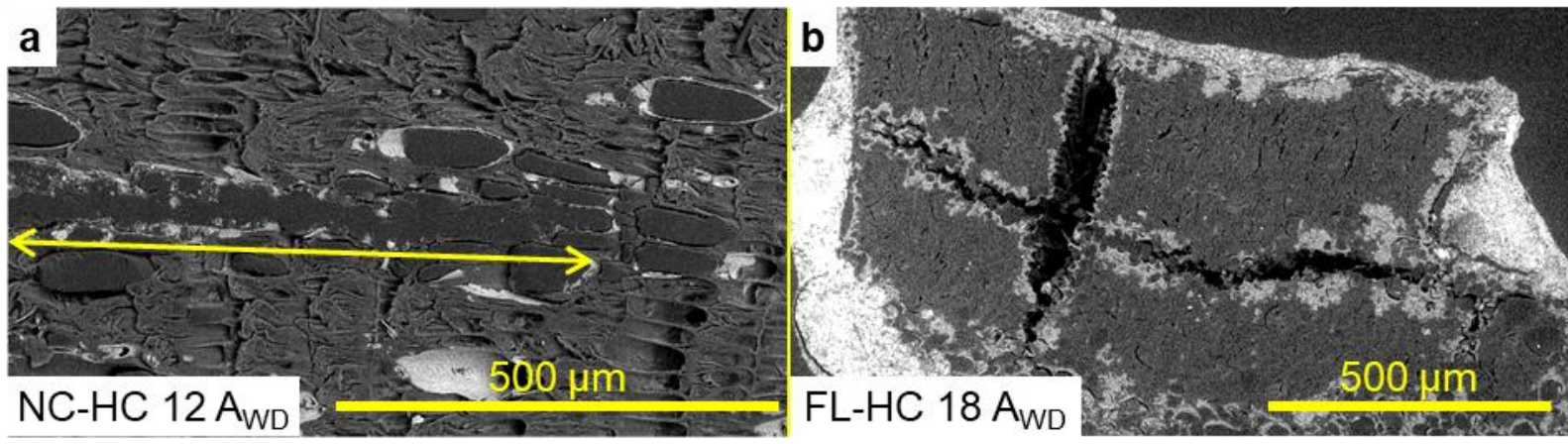

Figure 13. SEM observations of hemp shiv in concretes during $A_{W D}$ aging: crack within hemp shiv (a) in NC-HC after 12 months, (b) in FL-HC after 18 months

In order to better observe the structure inside hemp shiv, some vegetal particles are also collected from concretes and cut with a scalpel to observe cross-sections of the aggregates. For these observations, raw particles are analyzed without any preparation or metallization that could damage the plant cell walls. On these samples, hyphae are observed in plant cells (Figure 14-a). These hyphae are filaments that constitute the vegetative system of molds. Their formation during $A_{W D}$ aging means that fungal growth has occurred in the aggregates. A second phenomenon - decohesion of the vegetal cells - is also observed. It is characterized by the appearance of porosities between cells, corresponding to lignin degradation (Figure 14-b). A third type of degradation is the erosion of cell 
walls, visible through perforations in the plant wall (Figure 14-c). The diameter of a few tens of micrometers of these perforations and their random shapes distinguish them from visible pits in the lower left of the image, naturally present in plant walls. In this case, it indicates a degradation of the cellulose and hemicelluloses which are the main components of the cell wall. This wall degradation is also visible in Figure 14-d, obtained on a fragment of coated and polished hemp concrete. Indeed, while the plant wall initially has a thickness between 1 and $3 \mu \mathrm{m}$ (right side of the image), it is almost no longer visible on the lower left side of the image.
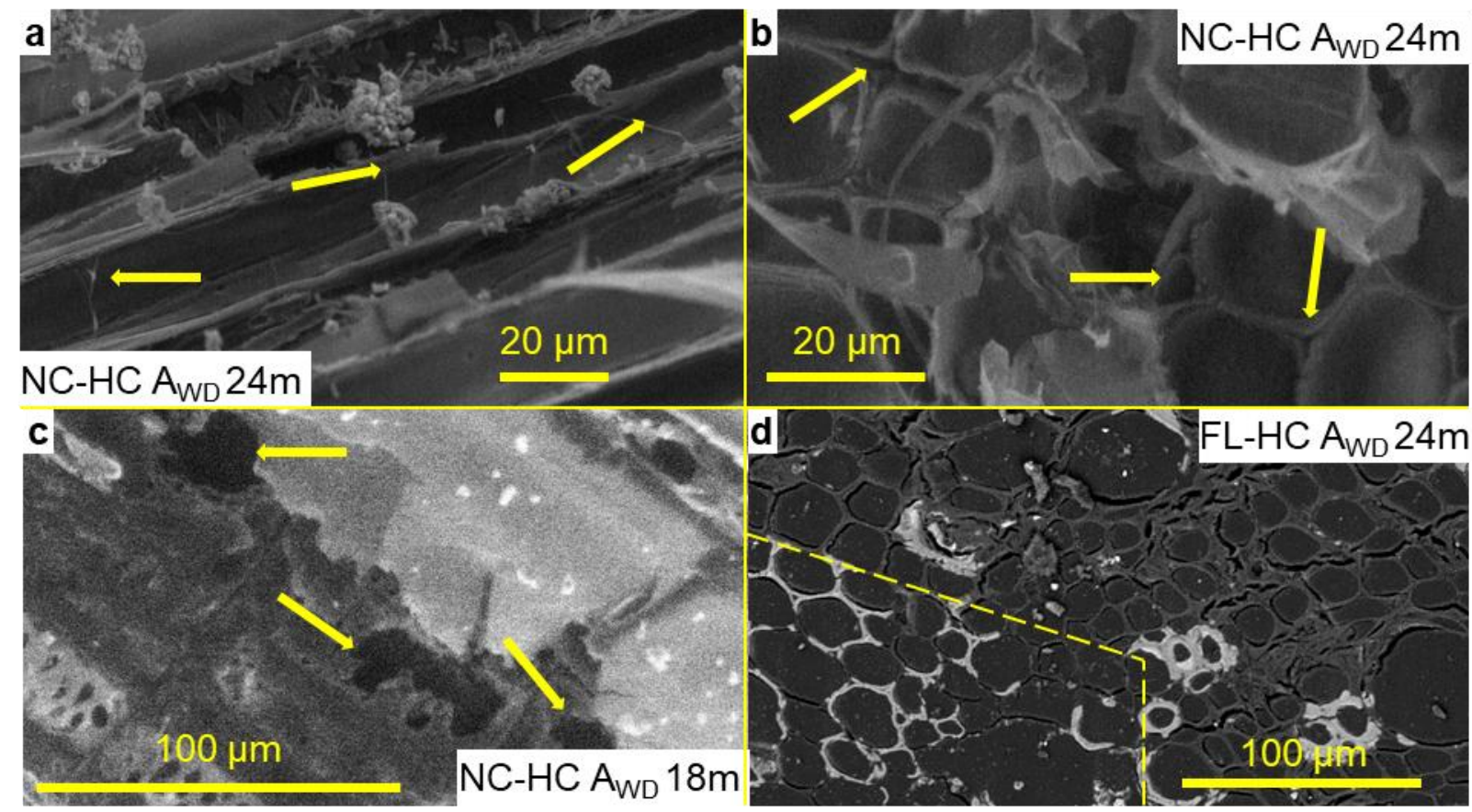

Figure 14. SEM observations on hemp shiv collected during $A_{W D}$ aging (a) Hyphae inside particles in $\mathrm{NC}-\mathrm{HC}$, (b) decohesion of vegetal cells in NC-HC, (c) erosion of cell wall in NC-HC, (d) decrease of vegetal wall thickness in hemp shiv in FL-HC

\subsubsection{Acoustical parameters}

From acoustic measurements, it is possible to determine parameters that describe the microstructure of hemp concretes: acoustic porosity $\Phi_{\text {acou }}$, resistivity $\sigma$, tortuosity $\alpha_{\infty}$ and viscous characteristic length $\Lambda$ [34]. The results obtained for FL-HC and NC-HC during aging are presented in Figure 15. In the case of reference aging $A_{R E F}$, the acoustic parameters do not change significantly over time and all the results obtained under these conditions are included in the gray band in Figure 15.

For $A_{W D}$ aging, acoustic porosity $\Phi_{\text {acou }}$ decreases from 0 to 3 months, and increases between 3 and 24 months for FL-HC $\left(p_{0-3}=9.6 .10^{-4}-p_{3-24}=5.6 .10^{-8}\right)$. For NC-HC, no evolution of acoustic porosity is observed between 0 and 3 months. An increase is then visible between 3 and 24 months $\left(p_{0-3}=0.13\right.$ $\left.\mathrm{p}_{3-24}=1 \cdot 2 \cdot 10^{-5}\right)$.

With regard to resistivity $\sigma$, an increase is visible between 0 and 3 months for FL-HC, followed by a decrease to 12 months and a further smaller increase to 24 months $\left(p_{0-3}=4.1 .10^{-4}-p_{3-12}=1.3 .10^{-4}\right.$ $\left.\mathrm{p}_{12-24}=8.5 \cdot 10^{-4}\right)$. The same trend is observed for NC-HC but to a less marked degree. While the 
variations are significant according to the ANOVA test, $p$ values are close to the fixed limit value of 0.05 between 0 and 3 months and between 3 months and 12 months $\left(p_{0-3}=0.03-p_{3-12}=0.03-p_{12-24}\right.$ $\left.=3 \cdot 3 \cdot 10^{-3}\right)$. Moreover, the variations remain of the same order of magnitude as the measurement variations for $A_{R E F}$.

Concerning tortuosity, $\alpha_{\infty}$ decreases drastically between 0 and 3 months for $\mathrm{FL}-\mathrm{HC}\left(\mathrm{p}_{0-3}=1.3 .10^{-9}\right)$. Then, it increases statistically significantly but does not return to its initial value after 24 months $\left(p_{3-24}=\right.$ $5.6 .10^{-8}$ ). This decrease of tortuosity does not appear in the first three months of aging for NC-HC. For this concrete, tortuosity increases up to 24 months $\left(p_{0-24}=4.5 .10^{-4}\right)$.

Finally, the viscous characteristic length $\Lambda$ determined for FL-HC follows the same variations as the resistivity, with an increase in its value between 0 and 3 months, a decrease up to 12 months, followed by a further increase to 18 months $\left(p_{0-3}=3.8 .10^{-3}-p_{3-12}=1.1 .10^{-3}-p_{12-18}=0.03-p_{18-24}=0.13\right)$. No significant variation of this parameter is observed for NC-HC. 

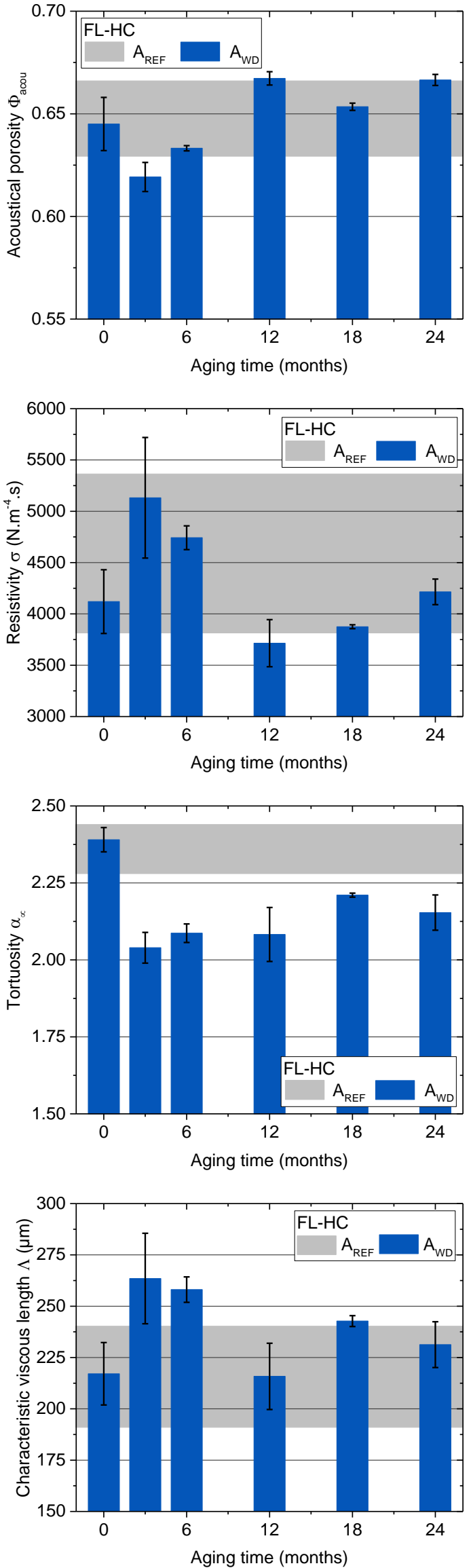
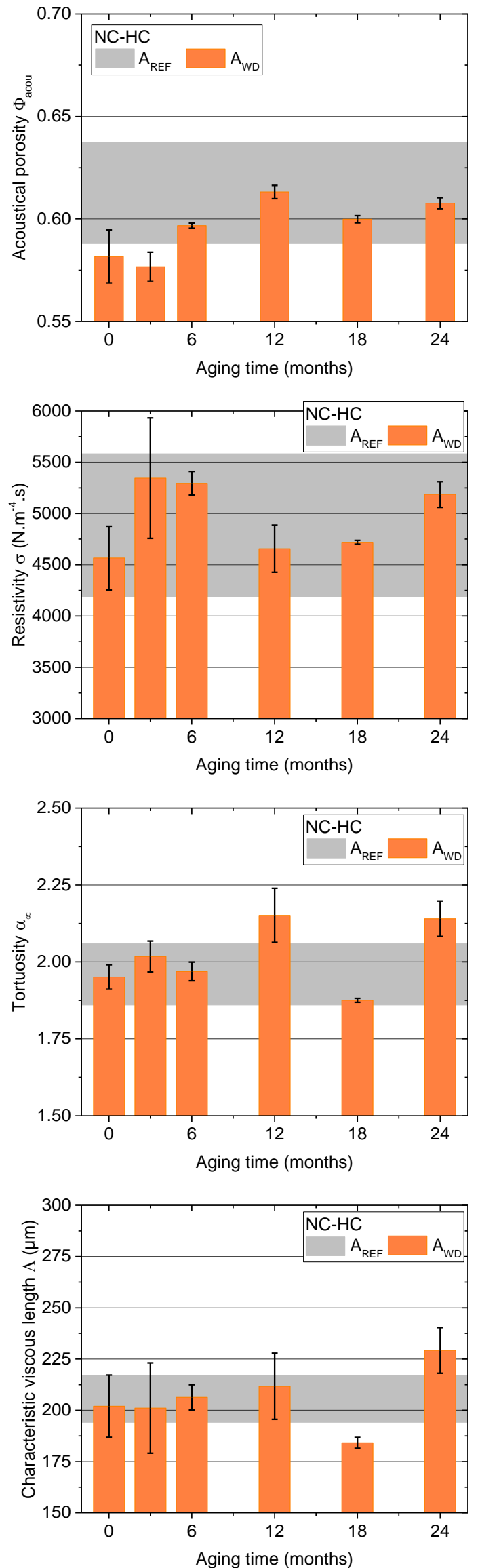

Figure 15. Evolution of the microstructural acoustical parameters 


\section{DISCUSSION}

The evolution of the properties of hemp concretes exposed to the two types of environments has been characterized at different scales, from functional to microstructural and mineralogical properties. The objective of this discussion is to link these different scales of analysis to highlight the main phenomena related to the aging of the materials studied in this work.

\subsection{Hemp concretes exposed to reference aging}

The various analyses presented in part 3 have shown that there is no significant evolution of the functional properties (thermal, acoustic, hydric or mechanical), the microstructure of hemp concretes or the mineralogical properties of the binder, whatever the formulation, during the 24 months of aging under reference conditions $A_{R E F}$. Therefore, both hemp concretes have stable properties over time under static conditions of $50 \% \mathrm{RH}$ and $20^{\circ} \mathrm{C}$.

\subsection{Hemp concretes subjected to accelerated aging}

The functional properties of hemp concretes evolve during accelerated aging $A_{W D}$, which consists of subjecting the samples to humidification and drying cycles. The variations measured depend on the type of binder used in the concrete. The thermal conductivity increases more significantly for FL-HC than for NC-HC. The sorption isotherms evolve similarly for both formulations. The acoustic properties change substantially only for FL-HC concrete while the mechanical properties do not change for either type of concrete. The microscopic analyses carried out account for these evolutions.

\subsubsection{Evolution of mineral matrix}

The chemical characterization of the binders during $A_{W D}$ aging shows a resumption of hydration of the binders for the two formulations, both at the surface and at the core of the specimen (Figure 7). This is due to the fact that, in the $A_{W D}$ conditions, the samples are exposed to a relative humidity higher than the $65 \%$ applied during curing. During periods of high relative humidity, the reaction of anhydrous compounds in the binders with water to form hydrates is favored. These chemical analyses of the binders also show that the humidity variations during the cycles promote the carbonation of portlandite or the $\mathrm{CSH}$ phases (equations 4 and 5) that react with the $\mathrm{CO}_{2}$ in the air (Figure 7). These reactions have impacts on several properties of the materials.

On the one hand, an increase in the density of the concretes is observed (Figure 8). At the same time, there is an increase in the thermal conductivity of the materials (Figure 3). This evolution of the thermal conductivity is directly related to the increase in density, and thus to the densification of the mineral phase (Figure 16). Several studies have already shown this link between thermal conductivity and density $[39,40]$. In addition, this densification is greater for FL-HC. It depends on the chemical nature of the binder [3]. 


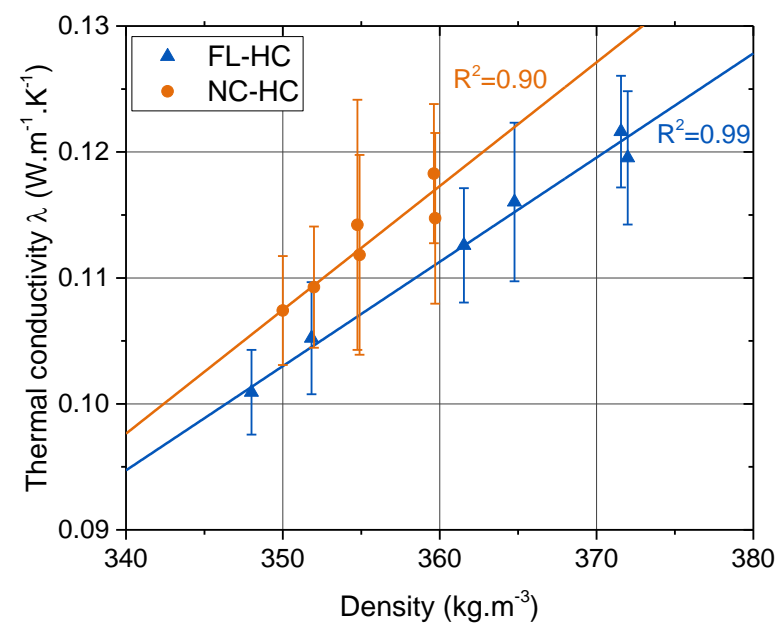

Figure 16. Thermal conductivity of hemp concretes as a function of density during $A_{W D}$ aging

On the other hand, Figure 7 shows that the chemical composition of the binders evolves rapidly on the surface of the specimens between 0 and 3 months; then, the hydration and carbonation reactions continue more slowly between 3 and 24 months. The same variations are observed as regards the resistivity of concretes (Figure 15): this parameter increases significantly between 0 and 3 months. The increase in resistivity between 12 and 24 months is attributable to the same phenomenon, which is always more marked for FL-HC (Figure 7). An additional phenomenon must be preponderant over the increase of density to explain the decrease in resistivity observed between 3 and 12 months. This phenomenon is described in the next paragraph.

However, despite the continuation of hydration and carbonation reactions during $A_{w D}$ aging, the latter take place more prominently at the surface and do not appear sufficiently advanced in the volume of the specimens to cause a significant increase in mechanical properties. Moreover, though the densification of the mineral matrix can lead to mechanical reinforcement, it is probably compensated by the degradation of the structure of hemp shiv, visible on SEM images (Figure 14). This being the case, it is difficult to decouple the behaviors of the two phases of the material in order to demonstrate a reinforcing effect on the concretes.

\subsubsection{Mineralization of hemp shiv porosity}

Electron microscopy observations on hemp concretes (Figure 12) show a mineralization of the porosity of hemp particles during $A_{W D}$ aging, mainly for FL-HC concretes. This mineralization is due to the diffusion of portlandite initially present in the binder around the vegetal particles [10,41]. During the humidification phase, water absorption by the concrete induces the solubilization of the portlandite, which can then diffuse inside the highly hydrophilic hemp shiv. During drying, the evaporation of water causes the precipitation of portlandite on the walls of the plant cells. This mineralization, visible from 3 month of $A_{W D}$ aging for FL-HC, modifies the porosity of the hemp particles (Figure 12).

This modification of pore dimensions has an impact on the dissipation of acoustic waves, as generally observed for porous materials [42]. In the initial state, before aging, tracheids (vegetal cells present in large quantities in hemp particles) have diameters of the order of 10 to $20 \mu \mathrm{m}$ and do not participate in acoustic dissipation [34]. In contrast, vessels, that have a larger diameter of about 50-80 $\mu \mathrm{m}$, can 
participate in sound dissipation. The porosity of these vessels represents less than $20 \%$ of the total sensitive porosity: interparticular porosity $\Phi_{\text {inter }}$ and hemp shiv vessels.

During the three first months of $A_{W D}$ aging, the vessels are mineralized and the pore size decreases, limiting the acoustic wave's access in the aggregates. The system evolves from double porosity to single porosity, with only the interparticle porosity $\Phi_{\text {inter }}$ being retained. The penetration of the acoustic wave into hemp particles is lower and the path through the material is more direct, which results in a decrease of tortuosity, as well as of acoustic porosity (Figure 15). These variations of $\alpha_{\infty}$ and $\Phi_{\text {acou }}$ shift the acoustic absorption curve towards the higher frequencies between 0 and three months of aging (Figure 4). This mineralization is much less visible for NC-HC (Figure 12), which contains less portlandite. This explains why, for this formulation, the acoustic properties remain stable over time during $A_{W D}$ aging.

\subsubsection{Degradation of vegetal cell walls}

Hemp concretes have a skeletal density $\rho_{\text {sk }}$ and an open air porosity $\Phi_{\text {air }}$ that increases with aging time up to 18 months (Figure 9 and Figure 10). This increase in open air porosity, also observed in the case of bulk hemp shiv [16], has an impact on acoustic parameters. In fact, acoustic porosity and tortuosity increase between 3 and 24 months for FL-HC and between 0 and 24 months for NC-HC. This means that the acoustic wave solicits more pores in the material - above all, the intraparticle porosity $\Phi_{\text {intra. }}$

This seems contradictory with the decrease in intraparticle pore size of plant particles observed in Figure 12 due to the mineralization of vegetal cells. However, observations of Figure 13 show cracks and holes that appear on vegetal walls. The cracks can be very wide (from 50 to $100 \mu \mathrm{m}$ ), and thus create a connection between porosities. This allows some porosities that were initially closed or inaccessible $\left(\Phi_{\text {intra_closed }}\right.$ in Figure 2$)$ to be opened $\left(\Phi_{\text {intra_open }}\right)$ and accessible to acoustic waves. They can be due to two phenomena: tearing of plant tissues during wetting and drying cycles of $A_{W D}$ aging, which cause particles to swell and shrink [7], or the consumption of plant walls by micro-organisms. Indeed, even if no mold growth has been observed on the surface of hemp concretes [18], hyphae are observed inside the particles (Figure 14). These two phenomena cause a modification of the microstructure of the plant - e.g. decohesion of the cells and reduction of the cell walls (Figure 14). This destructuration of vegetal cells increases the intraparticular porosity $\Phi_{\text {intra }}$ accessible to acoustic waves. The mass loss associated with these degradations explains the decrease in resistivity highlighted between 3 and 12 months of $A_{W D}$ aging (Figure 15). These phenomena also lead to an increase in the water vapor content with $A_{W D}$ aging (Figure 5) and in the specific surface of hemp concretes obtained from GAB model (Table 3).

The same results were observed on the aging of the bulk hemp shiv, subjected to the same aging conditions as the hemp concretes in this work [16]. In this study, the opening of the porosity of initially closed plant particles is almost complete, and their skeletal density varies from 860 to about 1400 $\mathrm{kg} \cdot \mathrm{m}^{-3}$. This latter value is close to that of the plant wall $\left(\approx 1480 \mathrm{~kg} \cdot \mathrm{m}^{-3}[16,45]\right)$. 
Using a mixing law based on the skeletal density of a hydraulic lime or cement [2] and assuming that can be calculated. The values obtained are respectively 2300 and $2660 \mathrm{~kg}^{-\mathrm{m}^{-3}}$ for a lime concrete and a cement concrete considering that the density of the cell wall is $1480 \mathrm{~kg} \cdot \mathrm{m}^{-3}$. However, the values measured in this study for hemp concretes are much lower, between 1400 and $1800 \mathrm{~kg} \cdot \mathrm{m}^{-3}$, both at $A_{90}$ and after 24 months of $A_{W D}$ aging (Figure 9). This indicates that a large proportion of closed porosity is still present in the material, but it is difficult to attribute it to the aggregate or binder. The opening of the porosities is similar for the two formulations of hemp concretes, meaning that the nature of the binder does not seem to have an impact on this modification of microstructure.

Consequently, given the increase in the porosity of hemp concretes compared to $A_{90}$, these materials can absorb a greater amount of water vapor, which is visible on the sorption isotherms, as observed in Figure 5 after 18 months of $A_{W D}$ aging.

\subsection{Durability of hemp concretes at the building scale}

The objective of this study is to assess the durability of hemp concretes through aging protocols applied in the laboratory to specimens of uncoated bulk materials, imposing static conditions of temperature and humidity or relative humidity variations. In order to be able to validate the variations of the properties measured over the course of two years in the two environments $A_{R E F}$ and $A_{W D}$, it is necessary to compare these results with those from studies carried out on walls or buildings made of hemp concrete. Before any comparison, it is important to note that in a building, hemp concrete is part of a construction system where it is protected inside and outside by a coating, for example. The choice of this construction system has an influence on the water content of hemp concrete walls.

Studies of real instrumented buildings or walls provide data on actual relative humidity in a hemp concrete wall, enabling us to evaluate the impact of coatings.

In a real building, the hygrothermal wall behavior of hemp concretes is monitored for four years [46]. In this study, a sand-lime plaster was immediately applied after the walls were built, which greatly slowed the drying of the walls. Therefore, high values of relative humidity, with daily outdoor variations between 60 and $95 \% \mathrm{RH}$, are measured the first year after construction. In addition, the excessively quick application of the coating to the wall before it has dried completely limits the carbonation of the binder [11]. Actually, the accumulation of water in hemp concrete behind the coating limits the diffusion of $\mathrm{CO}_{2}$ through the coating, as $\mathrm{CO}_{2}$ diffuses more rapidly in air than in water [13]. This water can also help to extract certain molecules from shiv that can inhibit hydration reactions $[47,48]$. Finally, micro-organisms can grow if the relative humidity remains high for a long time [29]. All the results show that these high relative humidity values can lead to early degradation of hemp concrete. In this study, they are due to the fact that the manufacturing conditions of hemp concretes are not those described in the building codes [6].

Other studies also focus on the impact of the properties of the coating applied on walls. First, it is shown that the render delays and reduces the diffusion of water vapor through the walls [49]. On hemp concrete test cells, exposed to external conditions but not inhabited [50], moisture content of the 
walls may increase in case of rain if the coating is permeable to liquid water. In the same way, if the increases because of the low diffusion of water vapor through the walls, which limits drying. Fungal development is then observed.

Vapor barrier films, often used to prevent fungal growth for insulating wools, do not prevent fungal growth in hemp concretes, as the amount of water present in the material is initially high [51]. On the contrary, damage can occur if vapor-impermeable materials are used, because it is then impossible for the hemp concrete to dry [5].

Under normal building usage conditions, when the hemp concrete building codes are followed [6], the relative humidity and temperature conditions are close to those corresponding to the reference aging $A_{\text {REF }}$ applied in this study. The results then show that the amount of water absorbed by the material is not sufficient to cause changes in the properties of hemp concretes, which have only been observed for higher relative humidity $(98 \% \mathrm{RH})$.

In studies on walls or buildings, where a coating has been applied to the surface of hemp concrete, it appears that processing not suited to the materials, either because of too short a drying time or an unsuitable choice of plaster, causes a high water content in hemp concrete. The conditions of use may then be close to the accelerated aging $A_{W D}$ applied in this study. The characterization of hemp concretes subjected to these conditions showed that they could lead to mineralization, swelling and shrinkage and fungal development in plant aggregates, causing degradation. Moreover, hydration and carbonation reactions are less advanced for mineral binders.

The results of this study will nevertheless have to be validated on hemp concrete collected from a real building after several years of use, as can be done for glass wool [27], in order to confirm the phenomena highlighted in this study and assess the lifetime of the materials.

\section{CONCLUSION}

In this study, the evolution of the functional properties of two hemp concretes formulated with two different binders is studied for two years according to different environmental conditions. These binders are a natural cement (NC) and a formulated lime-based binder (FL).

Stable environmental conditions $\left(50 \% \mathrm{RH}-20^{\circ} \mathrm{C}\right)$ have been applied to hemp concretes and constitute the reference aging $A_{\text {REF. }}$. In this case, no significant variation of the chemical, microstructural or functional properties is observed, whether in terms of the thermal, acoustic, hydric or mechanical behavior.

Accelerated aging in a climatic chamber is chosen to evaluate the evolution of hemp concretes when they are subjected to cycles alternating periods of high relative humidity ( 5 days at $98 \% \mathrm{RH}$ ) with phases of drying at lower relative humidity ( 2 days at $40 \% \mathrm{RH}$ ). Variations in functional properties are observed for both formulations. The thermal conductivity increases during aging and this increase is greater for FL-HC than for NC-HC. Regarding the hygric properties of the materials, an increase in the water vapor sorption capacity is observed between $20 \%$ and $60 \% \mathrm{RH}$. The acoustic properties do not 
change for NC-HC, while a decrease in acoustic performance is measured for FL-HC. Finally, no variation of mechanical properties is observed.

In order to understand these results obtained from the characterization of the functional properties, the chemical and microstructural properties of hemp concretes are analyzed during the two years of accelerated aging $A_{W D}$. Different factors having an impact on the properties of the materials are then highlighted:

- The hydration and carbonation reactions of the binder cause an increase in the density of the specimens and therefore in the thermal conductivity of the hemp concretes. The material is then a less effective insulator. However, these reactions are not sufficiently advanced in the core of the specimen to modify the mechanical strength of the concretes;

- The mineralization of the vegetal particles porosity by portlandite reduces the pore diameter of the shiv, limiting the accessibility of the aggregates to acoustic waves. The acoustic performance of the hemp concretes decreases compared to their initial state;

- The fungal development inside the aggregates and the swelling and shrinkage phenomena during the wetting and drying cycles lead to the opening of some porosities of the vegetal particles which were initially closed. The acoustic properties are then modified and more water vapor can be adsorbed in the hemp concrete, increasing the water vapor sorption capacity of the material.

The chemical nature of the binder has an impact on long-term variations of the performances of hemp concretes. Indeed, it has a role in the densification of the binder by carbonation and mineralization of the aggregates, which leads to modifications in thermal and acoustic properties.

Finally, the hygrothermal conditions measured in concrete walls of hemp under real conditions indicate a relative humidity lower than $70 \% \mathrm{RH}$ when the manufacturing conditions correspond to those described in the construction code. In this case, the evolution of the properties of the material over time is close to that observed in our study during reference aging $A_{\text {REF }}$. The performance of hemp concrete should therefore be stable for several years. This hypothesis must be verified by characterizing hemp concrete collected in a real building after several years of use. It will then be possible to validate the aging mechanisms proposed in this work and to evaluate a lifetime for the material.

\section{FUNDING}

The DVS measurements were supported by public funds received in the framework of SENSE-CITY, a project (ANR-10-EQPX-20) of the program 'Investissements d'Avenir' managed by the French National Research Agency.

\section{REFERENCES}

[1] S. Amziane, F. Collet, Bio-aggregates Based Building Materials, Springer, Dordrecht, 2017. doi:10.1007/978-94-024-1031-0. 
[2] P. Glé, Acoustique des Matériaux du Bâtiment à base de fibres et particules végétales - Outils de Caractérisation, Modélisation et Optimisation, Ecole Nationale Supérieure des Travaux Publics de l'Etat, 2013.

[3] E. Gourlay, Caractérisation expérimentale des propriétés mécaniques et hygrothermiques du béton de chanvre. Détermination de l'impact des matières premières et de la méthode de mise en oeuvre, Ecole Nationale Supérieure des Travaux Publics de l'Etat, 2014.

[4] G. Delannoy, S. Marceau, P. Glé, E. Gourlay, M. Guéguen-Minerbe, D. Diafi, I. Nour, S. Amziane, F. Farcas, Influence of binder on the multiscale properties of hemp concretes, Eur. J. Environ. Civ. Eng. (2018). doi:10.1080/19648189.2018.1457571.

[5] AQC, Isolants biosourcés: points de vigilance, 2017. http://www.qualiteconstruction.com/node/3008 (accessed August 28, 2019).

[6] Collectif SEBTP, Construire en Chanvre, Règles professionnelles d'exécution, 2012.

[7] V. Nozahic, S. Amziane, G. Torrent, K. Saïdi, H. De Baynast, Design of green concrete made of plant-derived aggregates and a pumice-lime binder, Cem. Concr. Compos. 34 (2012) 231241. doi:10.1016/j.cemconcomp.2011.09.002.

[8] A. Govin, Aspects physico-chimiques de l'interaction bois - ciment. Modification de l'hydratation du ciment par le bois, 2004. http://tel.archives-ouvertes.fr/docs/00/06/48/57/PDF/A-Govin.pdf.

[9] J. Wei, C. Meyer, Degradation mechanisms of natural fiber in the matrix of cement composites, Cem. Concr. Res. 73 (2015) 1-16. doi:10.1016/j.cemconres.2015.02.019.

[10] C. Magniont, G. Escadeillas, M. Coutand, C. Oms-Multon, Use of plant aggregates in building ecomaterials, Eur. J. Environ. Civ. Eng. $16 \quad$ (2012) s17-s33. doi:10.1080/19648189.2012.682452.

[11] A. Arizzi, M. Brümmer, I. Martín-Sánchez, E. Molina, G. Cultrone, Optimization of lime and clay-based hemp-concrete wall formulations for a successful lime rendering, Constr. Build. Mater. 184 (2018) 76-86. doi:10.1016/j.conbuildmat.2018.06.225.

[12] C. Magniont, Contribution à la formulation et à la caractérisation d'un écomatériau de construction à base d'agroressources, 2010. http://thesesups.upstlse.fr/980/1/Magniont_Camille.pdf.

[13] M. Chabannes, E. Garcia-Diaz, L. Clerc, J.-C. Bénézet, Effect of curing conditions and $\mathrm{Ca}(\mathrm{OH}) 2$-treated aggregates on mechanical properties of rice husk and hemp concretes using a lime-based binder, Constr. Build. Mater. 102, Part (2016) 821-833. doi:10.1016/j.conbuildmat.2015.10.206.

[14] C. Brischke, S. Thelandersson, Modelling the outdoor performance of wood products - A review on existing approaches, Constr. Build. Mater. 66 (2014) 384-397. doi:10.1016/j.conbuildmat.2014.05.087.

[15] T. Noguchi, E. Obataya, K. Ando, Effects of aging on the vibrational properties of wood, J. Cult. 
Herit. 13 (2012) S21-S25. doi:10.1016/j.culher.2012.02.008.

[16] G. Delannoy, S. Marceau, P. Glé, E. Gourlay, M. Guéguen-Minerbe, D. Diafi, I. Nour, S. Amziane, F. Farcas, Aging of hemp shiv used for concrete, Mater. Des. (2018). doi:10.1016/j.matdes.2018.10.016.

[17] R. Walker, S. Pavía, Moisture transfer and thermal properties of hemp-lime concretes, Constr. Build. Mater. 64 (2014) 270-276. doi:10.1016/j.conbuildmat.2014.04.081.

[18] G. Delannoy, M. Guéguen-Minerbe, I. Nour, S. Marceau, P. Glé, E. Gourlay, D. Diafi, S. Amziane, F. Farcas, Impacts of alkalinity and environmental ageing on fungal growth in hemp concretes, in: A. Bertron, H. Jonkers (Eds.), Final Conf. RILEM TC 253-MCI, Toulouse, 2018: pp. 347-354. https://rilem-mci2018.sciencesconf.org/resource/page/id/5 (accessed August 28, 2019).

[19] A. Arizzi, H. Viles, I. Martín-Sanchez, G. Cultrone, Predicting the long-term durability of hemplime renders in inland and coastal areas using Mediterranean, Tropical and Semi-arid climatic simulations, Sci. Total Environ. 542, Part (2016) 757-770. doi:10.1016/j.scitotenv.2015.10.141.

[20] S. Marceau, P. Glé, M. Guéguen-Minerbe, E. Gourlay, S. Moscardelli, I. Nour, S. Amziane, Influence of accelerated aging on the properties of hemp concretes, Constr. Build. Mater. (2017). doi:10.1016/j.conbuildmat.2016.11.129.

[21] S. C., M. Sonebi, S. Amziane, Investigation on the performance and durability of treated hemp concrete with water repellent, in: 2nd Int. Conf. Bio-Based Build. Mater., 2017.

[22] E. Sassoni, S. Manzi, A. Motori, M. Montecchi, M. Canti, Experimental study on the physicalmechanical durability of innovative hemp-based composites for the building industry, Energy Build. 104 (2015) 316-322. doi:10.1016/j.enbuild.2015.07.022.

[23] S. Marceau, G. Delannoy, Durability of bio-based concretes, 2017. doi:10.1007/978-94-0241031-0 8.

[24] S. Amziane, F. Collet, M. Lawrence, C. Magniont, V. Picandet, M. Sonebi, Recommendation of the RILEM TC 236-BBM : characterisation testing of hemp shiv to determine the initial water content, water absorption, dry density , particle size distribution and thermal conductivity, Mater. Struct. (2017). doi:10.1617/s11527-017-1029-3.

[25] V.H. Dodson, Pozzolans and the Pozzolanic Reaction, in: Concr. Admixtures, Springer US, Boston, MA, 1990: pp. 159-201. doi:10.1007/978-1-4757-4843-7_7.

[26] C. Gosselin, K.L. Scrivener, S.B. Feldman, W. Schwarz, The Hydration of Modern Roman Cements Used for Current Architectural Conservation, in: Hist. Mortars, Springer Netherlands, Dordrecht, 2012: pp. 297-308. doi:10.1007/978-94-007-4635-0_23.

[27] F. Stazi, F. Tittarelli, G. Politi, C. Di Perna, P. Munafò, Assessment of the actual hygrothermal performance of glass mineral wool insulation applied 25 years ago in masonry cavity walls, Energy Build. 68 (2014) 292-304. doi:10.1016/j.enbuild.2013.09.032. 
[28] E. Gourlay, P. Glé, S. Marceau, C. Foy, S. Moscardelli, Effect of water content on the acoustical and thermal properties of hemp concretes, Constr. Build. Mater. (2017). doi:10.1016/j.conbuildmat.2016.11.018.

[29] S. Marceau, P. Glé, M. Guéguen-Minerbe, E. Gourlay, S. Moscardelli, I. Nour, S. Amziane, Influence of accelerated aging on the properties of hemp concretes, Constr. Build. Mater. 139 (2017) 524-530. doi:10.1016/j.conbuildmat.2016.11.129.

[30] C. Niyigena, S. Amziane, A. Chateauneuf, L. Arnaud, L. Bessette, F. Collet, C. Lanos, G. Escadeillas, M. Lawrence, C. Magniont, S. Marceau, S. Pavia, U. Peter, V. Picandet, M. Sonebi, P. Walker, Variability of the mechanical properties of hemp concrete, Mater. Today Commun. 7 (2016) 122-133. doi:10.1016/j.mtcomm.2016.03.003.

[31] B. Mazhoud, F. Collet, S. Pretot, J. Chamoin, Hygric and thermal properties of hemp-lime plasters, Build. Environ. 96 (2016) 206-216. doi:10.1016/j.buildenv.2015.11.013.

[32] Y. Jiang, M. Ansell, X. Jia, A. Hussain, M. Lawrence, Physical characterisation of hemp shiv: Cell wall structure and porosity, in: 2nd Int. Conf. Bio-Based Build. Mater., Clermont-Ferrand, 2017. http://eprints.whiterose.ac.uk/116882/ (accessed August 28, 2019).

[33] P. Leclaire, O. Umnova, K. V. Horoshenkov, L. Maillet, Porosity measurement by comparison of air volumes, Rev. Sci. Instrum. 74 (2003) 1366-1370. doi:10.1063/1.1542666.

[34] P. Glé, E. Gourdon, L. Arnaud, Modelling of the acoustical properties of hemp particles, Constr. Build. Mater. 37 (2012) 801-811. doi:10.1016/j.conbuildmat.2012.06.008.

[35] S.A. Glantz, B.K. Slinker, T.B. Neilands, Primer of applied regression \& analysis of variance, McGraw-Hil, McGraw-Hill, 2016.

[36] K.S.W. Sing, D.H. Everett, R.A.W. Haul, L. Moscou, R.A. Pierotti, J. Rouquerol, T. Siemieniewska, Reporting Physisorption Data for Gas/Solid Systems with Special Reference to the Determination of Surface Area and Porosity, Pure Appl. Chem. 57 (1985) 603-619. doi:10.1351/pac198557040603.

[37] F. Collet, M. Bart, L. Serres, J. Miriel, Porous structure and water vapour sorption of hempbased materials, Constr. Build. Mater. 22 (2008) 1271-1280. doi:10.1016/j.conbuildmat.2007.01.018.

[38] G. Delannoy, S. Marceau, P. Glé, E. Gourlay, M. Guéguen-Minerbe, D. Diafi, S. Amziane, F. Farcas, Impact of hemp shiv extractives on hydration of Portland cement, Constr. Build. Mater. 244 (2020) 118300. doi:10.1016/j.conbuildmat.2020.118300.

[39] V. Cérézo, Cerezo, Propriétés mécaniques, thermiques et acoustiques d'un matériau à base de particules végétales: approche expérimentale et modélisation théorique, 2005. http://theses.insa-lyon.fr/publication/2005ISAL0037/these.pdf.

[40] F. Collet, S. Pretot, Thermal conductivity of hemp concretes: Variation with formulation, density and water content, Constr. Build. Mater. 65 (2014) 612-619. 
doi:10.1016/j.conbuildmat.2014.05.039.

[41] R.D. Toledo Filho, F. de A. Silva, E.M.R. Fairbairn, J. de A.M. Filho, Durability of compression molded sisal fiber reinforced mortar laminates, Constr. Build. Mater. 23 (2009) 2409-2420. doi:10.1016/j.conbuildmat.2008.10.012.

[42] K. V. Horoshenkov, M.J. Swift, The acoustic properties of granular materials with pore size distribution close to log-normal, J. Acoust. Soc. Am. 110 (2001) 2371-2378. doi:10.1121/1.1408312.

[43] Y. Jiang, M. Lawrence, M.P. Ansell, A. Hussain, Cell wall microstructure, pore size distribution and absolute density of hemp shiv, R. Soc. Open Sci. 5 (2018) 171945. doi:10.1098/rsos.171945.

[44] I. Ceyte, Béton de chanvre, définition des caractéristiques mécaniques de la chènevotte, Travail de fin d'études, ENTPE, 2008.

[45] V. Picandet, Bulk Density and Compressibility, in: Springer, Dordrecht, 2017: pp. 111-124. doi:10.1007/978-94-024-1031-0_5.

[46] B. Moujalled, Y. Aït Ouméziane, S. Moissette, M. Bart, C. Lanos, D. Samri, Experimental and numerical evaluation of the hygrothermal performance of a hemp lime concrete building: A long term case study, Build. Environ. 136 (2018) 11-27. doi:10.1016/J.BUILDENV.2018.03.025.

[47] Y. Diquélou, E. Gourlay, L. Arnaud, B. Kurek, Impact of hemp shiv on cement setting and hardening: Influence of the extracted components from the aggregates and study of the interfaces with the inorganic matrix, Cem. Concr. Compos. 55 (2015) 112-121. doi:10.1016/j.cemconcomp.2014.09.004.

[48] G. Delannoy, S. Marceau, P. Glé, E. Gourlay, M. Guéguen-Minerbe, D. Diafi, S. Amziane, F. Farcas, Impact of hemp shiv extractives on hydration of Portland Cement, Constr. Build. Mater. Submitted (2019).

[49] F. Collet, S. Pretot, Experimental highlight of hygrothermal phenomena in hemp concrete wall, Build. Environ. (n.d.). doi:10.1016/j.buildenv.2014.09.018.

[50] T. Bejat, A. Piot, A. Jay, L. Bessette, Study of two hemp concrete walls in real weather conditions, Energy Procedia. 78 (2015) 1605-1610. doi:10.1016/j.egypro.2015.11.221.

[51] E. Latif, M.A. Ciupala, S. Tucker, D.C. Wijeyesekera, D.J. Newport, Hygrothermal performance of wood-hemp insulation in timber frame wall panels with and without a vapour barrier, Build. Environ. 92 (2015) 122-134. doi:10.1016/j.buildenv.2015.04.025. 